\title{
Synthesis and Structure-Activity Relationships of New Benzodioxinic Lactones as Potential Anticancer Drugs
}

\author{
Manel Romero ${ }^{\dagger}$ Pierre Renard, ${ }^{\ddagger}$ Daniel-Henry Caignard, ${ }^{\ddagger}$ Ghanen Atassi, ${ }^{\ddagger}$ Xavier Solans, ${ }^{\S}$ Pere Constans, ${ }^{\dagger}$ Christian Bailly, ${ }^{\prime \prime}$ and \\ Maria Dolors Pujol*,† \\ Laboratori de Química Farmacèutica (Unitat Associada al CSIC), Facultat de Farmàcia, Universitat de Barcelona, Av. Diagonal 643, \\ 08028-Barcelona, Spain, Les Laboratoires Servier, 1 rue Carle Hebert, 92415-Courbevoie Cedex, France, Departament de Cristallografia, \\ Mineralogia i Dipòsits Minerals, Facultat de Geologia, Universitat de Barcelona, C/ Martí i Franquès s/n, 08028-Barcelona, Spain, and \\ INSERM U-524, IRCL, Place de Verdum, 59045 Lille, France
}

Received October 11, 2006

A set of disubstituted tetracyclic lactones has been synthesized and tested for potential antitumor activity. Several of them possess a noticeable cytotoxicity against L1210 and HT-29 colon cells in vitro. Relationships between chain nature and biological properties were sought. Lactones with a pentyl or hexyl substituent at $\mathrm{C}-11$ are the most active ones. The introduction of a functional group at the side chain of $\mathrm{C}-11$ modified the potency; carboxylic acid and primary amine decreased the cytotoxicity, whereas a cyano group increased the activity. An extensive structure-activity relationship study of these derivatives, including carbon homologues and bioisosteres has been performed. The synthesis and cytotoxicity of these compounds are discussed. Two lactones are recognized as potential lead compounds.

\section{Introduction}

Anticancer drugs have been classified according to the origin or the mechanism of action involved as antitumor antibiotic, antimetabolites, antitubulin agents, topoisomerase inhibitors, alkylating agents, and miscellaneous agents. ${ }^{1}$ In recent years, difficulties in classifying new antitumoral compounds have arisen. Several of them exhibit multiple mechanisms of action in tumor cells and many demonstrate a wide range of biochemical and pharmacological properties. Major progress in chemotherapy requires new and useful antitumor agents to eradicate the entire range of cancer diseases in the world over. New compounds can be developed by a wide variety of approaches, ranging from empirical screening to rational design: (a) from natural products, (b) by screening of synthetic compounds prepared for other purposes, and (c) by semisynthesis or total synthesis using new biological concepts and structure-activity relationships of potentially interesting known compounds. ${ }^{2}$

It has been established that ellipticine, a drug isolated from Ochrosia elliptica (Apocinaceae), has powerful antiproliferative properties. Its chemical structure consists in a tetracyclic skeleton composed of pyridine fused with the carbazole system (subunits $\mathrm{X}$ and Y). ${ }^{3}$ Ellipticine and related compounds exert their cytotoxic and antineoplastic effects by a multimodal mechanism of biological action (inhibition of DNA-topoisomerase II, DNAintercalation, covalent binding to DNA, and redox generation of cytotoxic free radicals). ${ }^{4}$ Several quaternary ellipticinium salts (datelliptium, pazellipticine, and others) were previously reported to possess high cytotoxic activity. ${ }^{5}$ Datelliptium and pazellipticine bearing hydrophilic substituents on a pyridine ring which increase water solubility were pursued as targets for synthesis (Chart 1$)^{5}$

These antitumor compounds are clinically effective, albeit they might cause serious adverse reactions. The toxicity of the

\footnotetext{
* To whom correspondence should be addressed. Phone: 003493 4024534. Fax: 003493 4035941. E-mail: mdpujol@ub.es.

† Laboratori de Química Farmacèutica, Facultat de Farmàcia, Universitat de Barcelona.

$\doteqdot$ Laboratoires Servier.

$\S$ Facultat de Geologia, Universitat de Barcelona.

"INSERM U-524, IRCL, Place de Verdum, 59045 Lille, France.
}

great majority of the antitumor compounds, both alone and in combination with other antitumor agents, is a reason for their restricted deployment. These problems motivate the research of new compounds. There has been an enormous amount of effort directed toward the research of new anticancer agents, related or not, to known compounds and the elucidation of their structure-activity relationships.

The presence of polycyclic lactones in a wide variety of antineoplastic compounds of natural or synthetic origin 6 induced us to introduce this structural motif in a new research line. It is well documented that compounds possessing a butyrolactone fused to a polycyclic system, such as podophyllotoxin ${ }^{7}$ or their semi-synthetic analogues etoposide and teniposide, ${ }^{8}$ show an interesting cytotoxic and antitumor activity.

The relationships between structure and cytotoxicity from inhibition of topoisomerase II are not yet well established, and the research of further classes of new antitumor agents remains of high interest. We have previously studied 1,4-benzodioxinoisoquinolines designed and synthesized as related analogues to the ellipticine. ${ }^{9}$ They are formally derived by substitution of the indole with a 1,4-benzodioxine subunit. This substitution leads to analogues that retain a noticeable in vitro cytotoxic activity. Structurally, they possess a basic nitrogen atom suitable for the DNA-intercalation. At a physiological $\mathrm{pH}$, these compounds are ionized and it is expected as a limitation of their applicability. The present investigation was undertaken to determine the effect of introducing a nonbasic lactone instead of a pyridine. Therefore, we decided to further investigate a novel tetracyclic system consisting on an 1,4-benzodioxine skeleton fused with a benzofuranone, to form the new isobenzofuro[5,6- $b][1,4]$ benzodioxines depicted in Chart 2. The aim of the present study was to establish new structure requirements for these new compounds and determine structural tolerances for cytotoxic activity in cancer cell cultures.

We focused our attention on the lactone due to its appealing antitumor activity for epipodophyllotoxins, such as etoposide, tenoposide, ${ }^{8}$ and other topoisomerase II inhibitors containing this moiety. The 1,4-benzodioxine, whose synthesis has been developed by us, was also chosen as a heterocyclic bioisostere 
Chart 1. Chemical Structures of Ellipticine, Datelliptium, and Etoposide
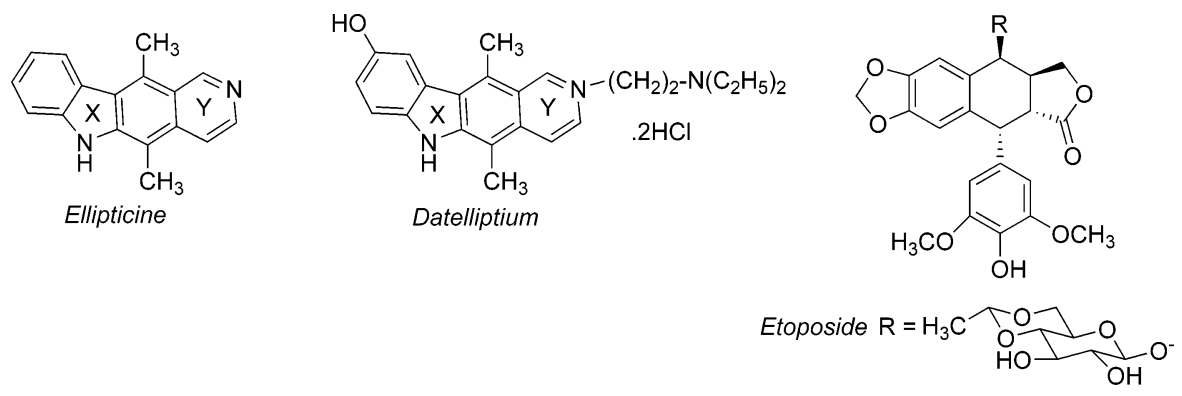

Chart 2. Design of Compounds 1-19 from Ellipticine

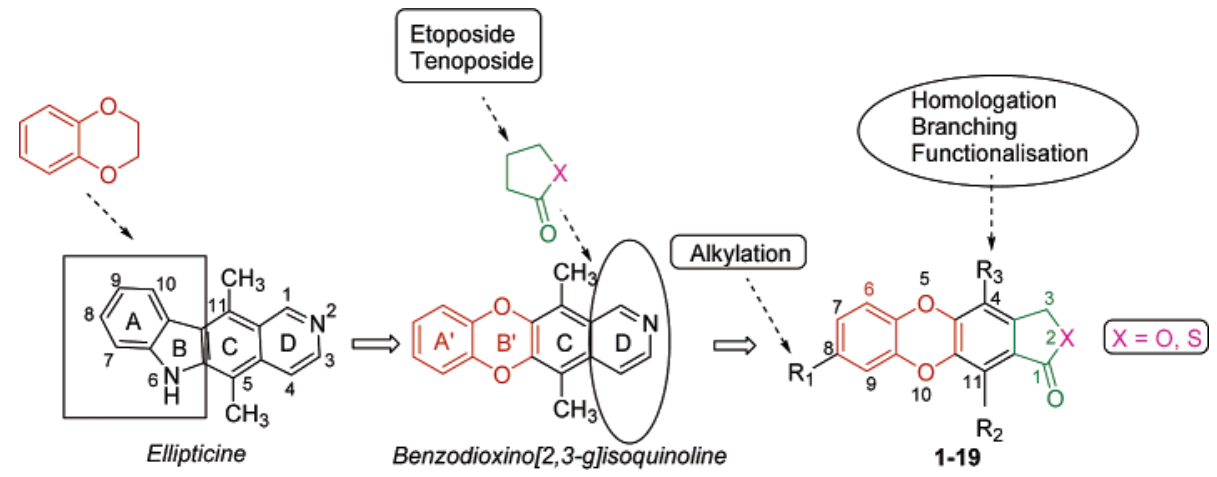

of indole. ${ }^{9}$ Structure-activity relationship studies and theoretical determination of relevant parameters to their cytotoxic activity were very useful in the design and development of new compounds.

To our knowledge, the isobenzofuro[5,6- $b][1,4]$ benzodioxine system has not previously been incorporated into an antitumor structure. Several modifications maintaining the same backbone were carried out, as those indicated in Chart 2: (a) modification of the $\mathrm{R}_{2}$ and $\mathrm{R}_{3}$ substituents, (b) modifications on the lactone ring, and (c) alkylation of the 1,4-benzodioxine ring.

\section{Chemistry}

Our initial task was to establish the most efficient method for performing the synthesis of the tetracyclic lactones $(\mathbf{1}, \mathbf{2} \mathbf{a}-$ $\mathbf{8 a}, \mathbf{2 b}-\mathbf{8 b}$ ) from the carboxylic acids $\mathbf{2 0}$ and $\mathbf{2 1}$. The results are summarized in Schemes 1-3.

Treatment of 1,4-benzodioxin-6-yl carboxylic acids (20 and 21) with LDA and subsequent addition of the corresponding aldehyde allowed the preparation of the desired hydroxyacids $(\mathbf{2 2}-\mathbf{3 4})$. After the ring closure of the hydroxyacids (22-34) using PTSA ( $p$-toluenesulfonic acid monohydrate) as catalyst in toluene at reflux led to the lactones $(\mathbf{3 5}-\mathbf{4 7})$ in very high yields. ${ }^{10-11}$

The intermediate lactones $(35-47)$ were treated with alkyllithium followed by the addition of trimethylsilylchloride at -78 ${ }^{\circ} \mathrm{C}$ to give the furo-derivatives $(\mathbf{4 8}-\mathbf{6 2})$. These dienes were relatively stable at low temperatures but unstable at room temperature. ${ }^{12}$

Finally, the treatment of the furo[3,4- $b][1,4]$ benzodioxines $(48-62)$ with the lactone $(63)$ or the thiolactone $(64)$ in acidic media $\left(\mathrm{Yb}(\mathrm{OTf})_{3}, \mathrm{BF}_{3} . \mathrm{Et}_{2} \mathrm{O}, \mathrm{SnCl}_{4}\right.$, or $\left.\mathrm{TiCl}_{4}\right)$ gives a mixture of tetracyclic lactones $a$ and $b$ in acceptable yields. Surprisingly, the expected Diels-Alder mixture of exo-endo adducts was not detected by reason of the facile cyclodehydration catalyzed by Lewis acid of the intermediate 1,4-epoxy-derivatives to the aromatic compounds. Aromatization of similar adducts by dehydration was generally effected by using catalytic amounts of acid. ${ }^{13}$ Several Lewis acids were tested as catalysts in the cycloaddition of the diene $\mathbf{4 8}$ and the $2(5 H)$-furanone at $90{ }^{\circ} \mathrm{C}$. The results shown in the Table 1 indicate that $\mathrm{Yb}(\mathrm{OTf})_{3}$ is the best catalyst for this cycloaddition reaction. When $\mathrm{TiCl}_{4}$ as a typical Lewis acid was used in $\mathrm{CH}_{2} \mathrm{Cl}_{2}$, the reaction could be only poorly observed. Moreover, the reaction of cycloaddition with $\mathrm{SiO}_{2}$ as catalyst did not lead to the desired product. On the other hand, it was found that $\mathrm{BF}_{3} \cdot \mathrm{Et}_{2} \mathrm{O}$ catalyzed the DielsAlder cycloaddition in lower yield than ytterbium(III) trifluoromethanesulfonate.

The one-pot formation of tetracyclic systems was investigated by using disubstituted dienes and lactone or thiolactone as dienophiles under the most suitable conditions at $90{ }^{\circ} \mathrm{C}$ in the presence of Lewis acid catalyst. It is noteworthy that a catalytic amount of Lewis acid is enough to give directly a mixture of two isomeric tetracyclic lactones $(a, b)$. The diene 60 was obtained with difficulties in little yield, possibly due to the interaction of the heteroatom in the side chain with the reagents used for its preparation. The reaction between diene $\mathbf{6 0}$ and lactone 63 leads to the complex mixture of degradation compounds (dicarbonyl compound, diol, etc.) instead of the expected lactones.

The mixture of isomeric compounds proved difficult to separate by usual methods, but finally, after extensive experimentation, the mixture could be separated by meticulous column chromatography on silica gel. The structure of the isomer obtained was judged from ${ }^{1} \mathrm{H}$ NMR and ${ }^{13} \mathrm{C}$ NMR spectra. X-ray experiments of the lactone $\mathbf{4 a}$ allowed us to unambiguously ascribe structure $a$ to the minor constituent of the mixture and structure $b$ to the main compound. Subsequent NMR studies agreed well with the X-ray structure (see Supporting Information).

To increase the number of structural changes, compounds $14,15,16$, and 19 were synthesized by transformation of the cyano-derivatives $12 \mathbf{a}$ and $\mathbf{1 3 a}$. Thus, base hydrolysis of the cyano-derivatives (12 and 13a) with $2 \mathrm{~N} \mathrm{NaOH}$ gave the corresponding carboxylic acids (14 and $\mathbf{1 5}$ ) in excellent yields. Based on molecular modeling, best activity was expected for the amine 16. Treatment of the appropriate nitrile with $\mathrm{H}_{2}$ in 
Scheme 1. Synthesis of Dienes 48-62

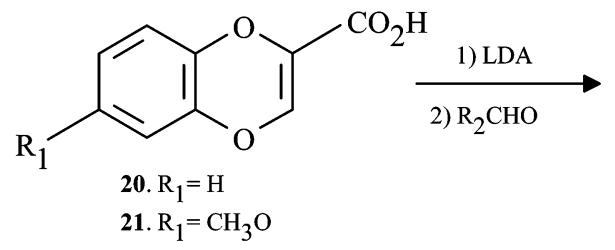<smiles>[R7][R7]=C</smiles>

23. $\mathrm{R}_{1}=\mathrm{H}, \mathrm{R}_{2}=\mathrm{CH}_{2} \mathrm{CH}_{3}$

24. $\mathrm{R}_{1}=\mathrm{H}, \mathrm{R}_{2}=\left(\mathrm{CH}_{2}\right)_{2} \mathrm{CH}_{3}$

25. $\mathrm{R}_{1}=\mathrm{H}, \mathrm{R}_{2}=\left(\mathrm{CH}_{2}\right)_{4} \mathrm{CH}_{3}$

26. $\mathrm{R}_{1}=\mathrm{H}, \mathrm{R}_{2}=\left(\mathrm{CH}_{2}\right)_{5} \mathrm{CH}_{3}$

27. $\mathrm{R}_{1}=\mathrm{H}, \mathrm{R}_{2}=\left(\mathrm{CH}_{2}\right)_{6} \mathrm{CH}_{3}$

28. $\mathrm{R}_{1}=\mathrm{H}, \mathrm{R}_{2}=\left(\mathrm{CH}_{2}\right)_{7} \mathrm{CH}_{3}$

29. $\mathrm{R}_{1}=\mathrm{H}, \mathrm{R} 2=\mathrm{CH}_{2} \mathrm{CH}\left(\mathrm{CH}_{3}\right) \mathrm{CH}_{2} \mathrm{C}\left(\mathrm{CH}_{3}\right)_{3}$

30. $\mathrm{R}_{1}=\mathrm{H}, \mathrm{R}_{2}=\left(\mathrm{CH}_{2}\right)_{4} \mathrm{Br}$

31. $\mathrm{R}_{1}=\mathrm{H}, \mathrm{R}_{2}=\mathrm{CH}_{2} \mathrm{OCH}_{2} \mathrm{C}_{6} \mathrm{H}_{5}$

32. $\mathrm{R}_{1}=\mathrm{CH}_{3} \mathrm{O}, \mathrm{R}_{2}=\left(\mathrm{CH}_{2}\right)_{4} \mathrm{CH}_{3}$

33. $\mathrm{R}_{1}=\mathrm{H}, \mathrm{R}_{2}=\left(\mathrm{CH}_{2}\right)_{4} \mathrm{CN}$

34. $\mathrm{R}_{1}=\mathrm{H}, \mathrm{R}_{2}=\left(\mathrm{CH}_{2}\right)_{5} \mathrm{CN}$

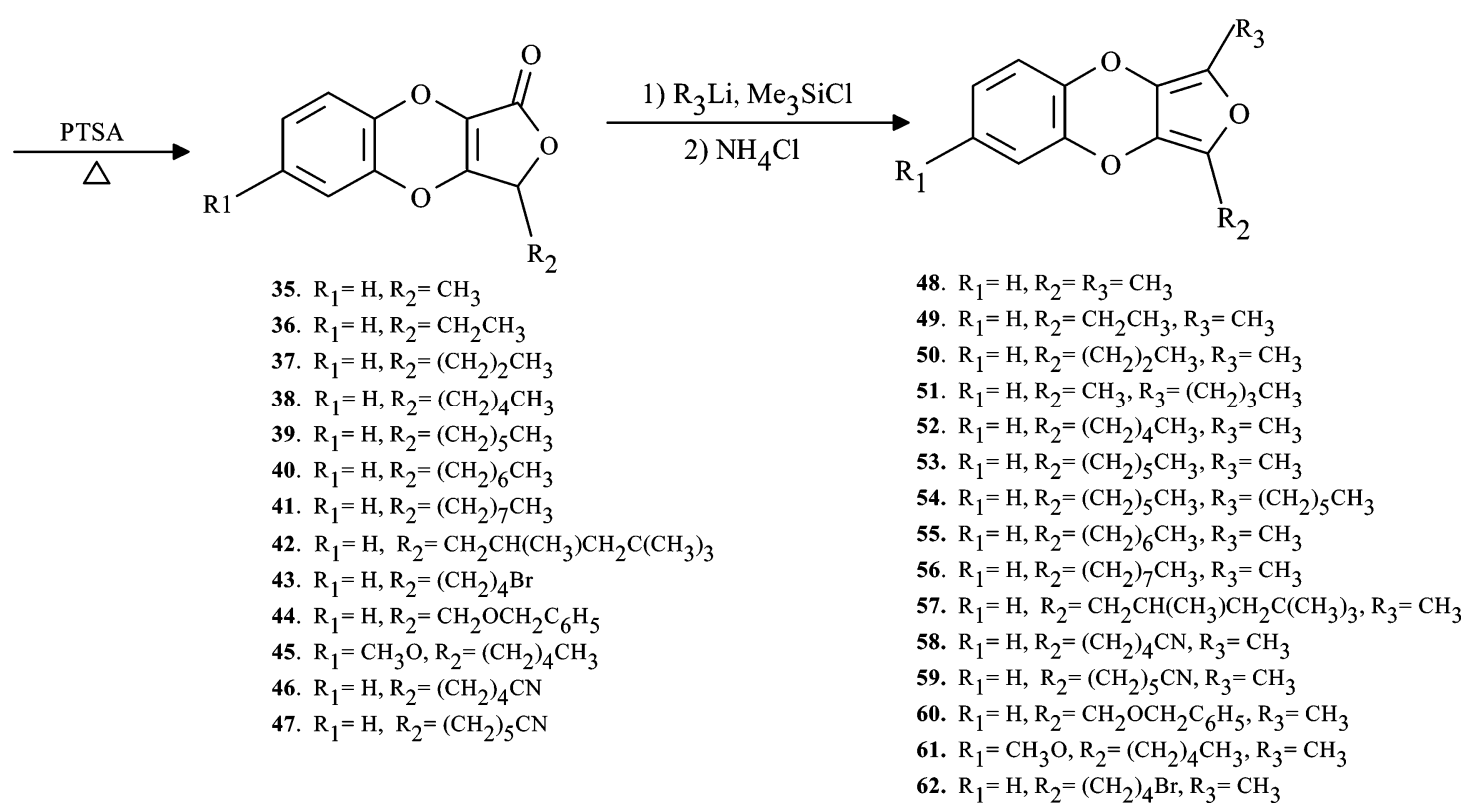

methanol using $\mathrm{PtO}_{2}$ as catalyst at room temperature afforded the corresponding amine in quantitative yields. The nucleophilic treatment of the bromide 18a with methylamine hydrochloride in basic media afforded the corresponding amine 19 in acceptable yield (Scheme 3).

\section{Results and Discussion}

Structure-Activity Relationship. Many experimental studies indicate that the size, shape, and planarity of the ellipticine and derivatives are important factors for their mechanism of cytotoxicity and antitumor activity. ${ }^{14}$ Furthermore, the acid-basic properties of ellipticine have been estimated. It is known that the pharmacological activities of drugs depend on their interaction. They are expected to be significantly different for the charged and uncharged drugs. ${ }^{15}$

A detailed similarity analysis, Figures 1 to 3 , has shown a remarkable structural coincidence of 1-oxo-3 $H$-isobenzofuro$[5,6-b][1,4]$ benzodioxine with the ellipticine nucleus. It is important to point out that only the behavior of the tetracyclic system was studied without considering the alkyl substituents.
This analysis was performed using fully optimized $a b$ initio geometries, and electron density overlaps as a measure of similarity. Geometries were found to be almost planar. The density overlap alignment at the global maximum of the similarity function is presented in Figure 1. Figures 1 and $2 c, d$ display the isocontour surface of the largest common pattern density, see Computational Methods for details and definitions. On the other hand, Figure 2a,b displays the electron density isocontours for the two molecules. The complete set of figures illustrates the extent of similarity, which embraces nearly the whole molecule but half of ring $\mathbf{A}$. In the figures, the surfaces were plotted at the isocontour value of 0.03 and $0.03^{2}$, in a.u., for the density and common pattern density, respectively, as being this value is an approximate equivalent for molecular accessible surface areas. Albeit being similar on an overall and structural analysis, the two electronic densities differ in some aspects. Differences on electronic rearrangements are manifest on the electrostatic potential maps. There are important differences in charge distribution among the studied compounds due to the presence of specific side groups. Figure 3 plots the density 
Scheme 2. Synthesis of Tetracyclic Lactones by Diels-Alder Cycloaddition<smiles>[R]c1ccc2c(c1)Oc1c([R2])oc([R3])c1O2</smiles>

48. $\mathrm{R}_{1}=\mathrm{H}, \mathrm{R}_{2}=\mathrm{CH}_{3}, \mathrm{R}_{3}=\mathrm{CH}_{3}$ 49. $\mathrm{R}_{1}=\mathrm{H}, \mathrm{R}_{2}=\mathrm{CH}_{2} \mathrm{CH}_{3}, \mathrm{R}_{3}=\mathrm{CH}_{3}$ 50. $\mathrm{R}_{1}=\mathrm{H}, \mathrm{R}_{2}=\left(\mathrm{CH}_{2}\right)_{2} \mathrm{CH}_{3}, \mathrm{R}_{3}=\mathrm{CH}_{3}$ 51. $\mathrm{R}_{1}=\mathrm{H}, \mathrm{R}_{2}=\mathrm{CH}_{3}, \mathrm{R}_{3}=\left(\mathrm{CH}_{2}\right)_{3} \mathrm{CH}_{3}$ 52. $\mathrm{R}_{1}=\mathrm{H}, \mathrm{R}_{2}=\left(\mathrm{CH}_{2}\right)_{4} \mathrm{CH}_{3}, \mathrm{R}_{3}=\mathrm{CH}_{3}$ 53. $\mathrm{R}_{1}=\mathrm{H}, \mathrm{R}_{2}=\left(\mathrm{CH}_{2}\right)_{5} \mathrm{CH}_{3}, \mathrm{R}_{3}=\mathrm{CH}_{3}$ 54. $\mathrm{R}_{1}=\mathrm{H}, \mathrm{R}_{2}=\left(\mathrm{CH}_{2}\right)_{5} \mathrm{CH}_{3}, \mathrm{R}_{3}=\left(\mathrm{CH}_{2}\right)_{5} \mathrm{CH}_{3}$ 55. $\mathrm{R}_{1}=\mathrm{H}, \mathrm{R}_{2}=\left(\mathrm{CH}_{2}\right)_{6} \mathrm{CH}_{3}, \mathrm{R}_{3}=\mathrm{CH}_{3}$ 56. $\mathrm{R}_{1}=\mathrm{H}, \mathrm{R}_{2}=\left(\mathrm{CH}_{2}\right)_{7} \mathrm{CH}_{3}, \mathrm{R}_{3}=\mathrm{CH}_{3}$ 57. $\mathrm{R}_{1}=\mathrm{H}, \mathrm{R}_{2}=\mathrm{CH}_{2} \mathrm{CH}\left(\mathrm{CH}_{3}\right) \mathrm{CH}_{2} \mathrm{C}\left(\mathrm{CH}_{3}\right)_{3}, \mathrm{R}_{3}=\mathrm{CH}_{3}$ 58. $\mathrm{R}_{1}=\mathrm{H}, \mathrm{R}_{2}=\left(\mathrm{CH}_{2}\right)_{4} \mathrm{CN}, \mathrm{R}_{3}=\mathrm{CH}_{3}$ 59. $\mathrm{R}_{1}=\mathrm{H}, \mathrm{R}_{2}=\left(\mathrm{CH}_{2}\right)_{5} \mathrm{CN}, \mathrm{R}_{3}=\mathrm{CH}_{3}$ 60. $\mathrm{R}_{1}=\mathrm{H}, \mathrm{R}_{2}=\mathrm{CH}_{2} \mathrm{OCH}_{2} \mathrm{C}_{6} \mathrm{H}_{5}, \mathrm{R}_{3}=\mathrm{CH}_{3}$ 61. $\mathrm{R}_{1}=\mathrm{CH}_{3} \mathrm{O}, \mathrm{R}_{2}=\left(\mathrm{CH}_{2}\right)_{4} \mathrm{CH}_{3}, \mathrm{R}_{3}=\mathrm{CH}_{3}$ 62. $\mathrm{R}_{1}=\mathrm{H}, \mathrm{R}_{2}=\left(\mathrm{CH}_{2}\right)_{4} \mathrm{Br}, \mathrm{R}_{3}=\mathrm{CH}_{3}$

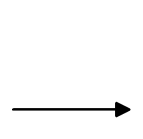<smiles>[R]c1ccc2c(c1)Oc1c([R])c3c(c([R2])c1O2)C[Y]C3=O</smiles>

1. $\mathrm{R}_{1}=\mathrm{H}, \mathrm{R}_{2}=\mathrm{CH}_{3}, \mathrm{R}_{3}=\mathrm{CH}_{3}, \mathrm{Y}=\mathrm{O}$

2a. $\mathrm{R}_{1}=\mathrm{H}, \mathrm{R}_{2}=\mathrm{CH}_{2} \mathrm{CH}_{3}, \mathrm{R}_{3}=\mathrm{CH}_{3}, \mathrm{Y}=\mathrm{O}$

3a. $\mathrm{R}_{1}=\mathrm{H}, \mathrm{R}_{2}=\left(\mathrm{CH}_{2}\right)_{2} \mathrm{CH}_{3}, \mathrm{R}_{3}=\mathrm{CH}_{3}, \mathrm{Y}=\mathrm{O}$

4a. $\mathrm{R}_{1}=\mathrm{H}, \mathrm{R}_{2}=\left(\mathrm{CH}_{2}\right)_{3} \mathrm{CH}_{3}, \mathrm{R}_{3}=\mathrm{CH}_{3}, \mathrm{Y}=\mathrm{O}$

5a. $\mathrm{R}_{1}=\mathrm{H}, \mathrm{R}_{2}=\left(\mathrm{CH}_{2}\right)_{4} \mathrm{CH}_{3}, \mathrm{R}_{3}=\mathrm{CH}_{3}, \mathrm{Y}=\mathrm{O}$

6a. $\mathrm{R}_{1}=\mathrm{H}, \mathrm{R}_{2}=\left(\mathrm{CH}_{2}\right)_{5} \mathrm{CH}_{3}, \mathrm{R}_{3}=\mathrm{CH}_{3}, \mathrm{Y}=\mathrm{O}$

7a. $\mathrm{R}_{1}=\mathrm{H}, \mathrm{R}_{2}=\left(\mathrm{CH}_{2}\right)_{6} \mathrm{CH}_{3}, \mathrm{R}_{3}=\mathrm{CH}_{3}, \mathrm{Y}=\mathrm{O}$

8a. $\mathrm{R}_{1}=\mathrm{H}, \mathrm{R}_{2}=\left(\mathrm{CH}_{2}\right)_{7} \mathrm{CH}_{3}, \mathrm{R}_{3}=\mathrm{CH}_{3}, \mathrm{Y}=\mathrm{O}$

9. $\mathrm{R}_{1}=\mathrm{H}, \mathrm{R}_{2}=\left(\mathrm{CH}_{2}\right)_{5} \mathrm{CH}_{3}, \mathrm{R}_{3}=\left(\mathrm{CH}_{2}\right)_{5} \mathrm{CH}_{3}, \mathrm{Y}=\mathrm{O}$

10a. $\mathrm{R}_{1}=\mathrm{H}, \mathrm{R}_{2}=\mathrm{CH}_{2} \mathrm{CH}\left(\mathrm{CH}_{3}\right) \mathrm{CH}_{2} \mathrm{C}\left(\mathrm{CH}_{3}\right)_{3}, \mathrm{R}_{3}=\mathrm{CH}_{3}, \mathrm{Y}=\mathrm{O}$

11a. $\mathrm{R}_{1}=\mathrm{H}, \mathrm{R}_{2}=\left(\mathrm{CH}_{2}\right)_{5} \mathrm{CH}_{3}, \mathrm{R}_{3}=\mathrm{CH}_{3}, \mathrm{Y}=\mathrm{S}$

12a. $\mathrm{R}_{1}=\mathrm{H}, \mathrm{R}_{2}=\left(\mathrm{CH}_{2}\right)_{4} \mathrm{CN}, \mathrm{R}_{3}=\mathrm{CH}_{3}, \mathrm{Y}=\mathrm{O}$

13a. $\mathrm{R}_{1}=\mathrm{H}, \mathrm{R}_{2}=\left(\mathrm{CH}_{2}\right)_{5} \mathrm{CN}, \mathrm{R}_{3}=\mathrm{CH}_{3}, \mathrm{Y}=\mathrm{O}$

17a. $\mathrm{R}_{1}=\mathrm{CH}_{3} \mathrm{O}, \mathrm{R}_{2}=\left(\mathrm{CH}_{2}\right)_{4} \mathrm{CH}_{3}, \mathrm{R}_{3}=\mathrm{CH}_{3}, \mathrm{Y}=\mathrm{O}$

18a. $\mathrm{R}_{1}=\mathrm{H}, \mathrm{R}_{2}=\left(\mathrm{CH}_{2}\right)_{4} \mathrm{Br}, \mathrm{R}_{3}=\mathrm{CH}_{3}, \mathrm{Y}=\mathrm{O}$

19. $\mathrm{R}_{1}=\mathrm{H}, \mathrm{R}_{2}=\left(\mathrm{CH}_{2}\right)_{4} \mathrm{NHCH}_{3}, \mathrm{R}_{3}=\mathrm{CH}_{3}, \mathrm{Y}=\mathrm{O}$

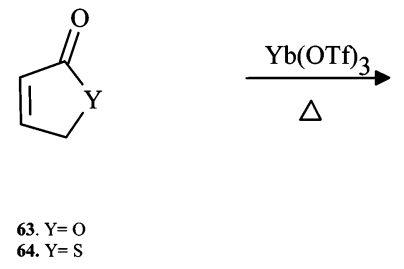

$+$<smiles>[R]c1ccc2c(c1)Oc1c([R2])c3c(c([R3])c1O2)C(=O)[Y]C3</smiles>

2b. $\mathrm{R}_{1}=\mathrm{H}, \mathrm{R}_{2}=\mathrm{CH}_{2} \mathrm{CH}_{3}, \mathrm{R}_{3}=\mathrm{CH}_{3}, \mathrm{Y}=\mathrm{O}$

3b. $\mathrm{R}_{1}=\mathrm{H}, \mathrm{R}_{2}=\left(\mathrm{CH}_{2}\right)_{2} \mathrm{CH}_{3}, \mathrm{R}_{3}=\mathrm{CH}_{3}, \mathrm{Y}=\mathrm{O}$

4b. $\mathrm{R}_{1}=\mathrm{H}, \mathrm{R}_{2}=\left(\mathrm{CH}_{2}\right)_{3} \mathrm{CH}_{3}, \mathrm{R}_{3}=\mathrm{CH}_{3}, \mathrm{Y}=\mathrm{O}$

5b. $\mathrm{R}_{1}=\mathrm{H}, \mathrm{R}_{2}=\left(\mathrm{CH}_{2}\right)_{4} \mathrm{CH}_{3}, \mathrm{R}_{3}=\mathrm{CH}_{3}, \mathrm{Y}=\mathrm{O}$

6b. $\mathrm{R}_{1}=\mathrm{H}, \mathrm{R}_{2}=\left(\mathrm{CH}_{2}\right)_{5} \mathrm{CH}_{3}, \mathrm{R}_{3}=\mathrm{CH}_{3}, \mathrm{Y}=\mathrm{O}$

7b. $\mathrm{R}_{1}=\mathrm{H}, \mathrm{R}_{2}=\left(\mathrm{CH}_{2}\right)_{6} \mathrm{CH}_{3}, \mathrm{R}_{3}=\mathrm{CH}_{3}, \mathrm{Y}=\mathrm{O}$

8b. $\mathrm{R}_{1}=\mathrm{H}, \mathrm{R}_{2}=\left(\mathrm{CH}_{2}\right)_{7} \mathrm{CH}_{3}, \mathrm{R}_{3}=\mathrm{CH}_{3}, \mathrm{Y}=\mathrm{O}$

10b. $\mathrm{R}_{1}=\mathrm{H}, \mathrm{R}_{2}=\mathrm{CH}_{2} \mathrm{CH}\left(\mathrm{CH}_{3}\right) \mathrm{CH}_{2} \mathrm{C}\left(\mathrm{CH}_{3}\right)_{3}, \mathrm{R}_{3}=\mathrm{CH}_{3}, \mathrm{Y}=\mathrm{O}$

11b. $\mathrm{R}_{1}=\mathrm{H}, \mathrm{R}_{2}=\left(\mathrm{CH}_{2}\right)_{5} \mathrm{CH}_{3}, \mathrm{R}_{3}=\mathrm{CH}_{3}, \mathrm{Y}=\mathrm{S}$

12b. $\mathrm{R}_{1}=\mathrm{H}, \mathrm{R}_{2}=\left(\mathrm{CH}_{2}\right)_{4} \mathrm{CN}, \mathrm{R}_{3}=\mathrm{CH}_{3}, \mathrm{Y}=\mathrm{O}$

13b. $\mathrm{R}_{1}=\mathrm{H}, \mathrm{R}_{2}=\left(\mathrm{CH}_{2}\right)_{5} \mathrm{CN}, \mathrm{R}_{3}=\mathrm{CH}_{3}, \mathrm{Y}=\mathrm{O}$

17b. $\mathrm{R}_{1}=\mathrm{CH}_{3} \mathrm{O}, \mathrm{R}_{2}=\left(\mathrm{CH}_{2}\right)_{4} \mathrm{CH}_{3}, \mathrm{R}_{3}=\mathrm{CH}_{3}, \mathrm{Y}=\mathrm{O}$

18b. $\mathrm{R}_{1}=\mathrm{H}, \mathrm{R}_{2}=\left(\mathrm{CH}_{2}\right)_{4} \mathrm{Br}, \mathrm{R}_{3}=\mathrm{CH}_{3}, \mathrm{Y}=\mathrm{O}$ isocontours colored according to the potential values. As expected, the electronegative $\mathrm{N}$ and $\mathrm{O}$ atoms exhibit negative charge. The polarized $\mathrm{N}^{\delta-}-\mathrm{H}^{\delta+}$ bond is also reflected in this particular isosurface because the surface goes nearby the indole H.

All prepared lactones (compounds 1-19) were assayed in vitro for the ability to inhibit cell proliferation L1210 (murine leukemia) and HT-29 (human colon carcinoma). ${ }^{16}$ Also, the action over the phases of cell cycle was considered on the first cell line (L1210). The results expressed as $\mathrm{IC}_{50}$ values (mean of at least 4 determinations in triplicate obtained in independent experiments with variations of $<5 \%$ ) are listed in Table 2 . The lactone 4a was also evaluated against 60 tumor cell lines in the NCI (National Cancer Institute, MD). ${ }^{17}$ The cytotoxic activity of these compounds was compared with the activity of ellipticine and adriamycin, both known antitumor compounds. Ellipticine and adriamycin were the chosen patterns for their structural similarity and for possessing bulky side chains, respectively.

Some of these compounds were found to possess significant activity at micromolar concentration. For analyzing structureactivity relationships, four structural components are considered: (a) the presence of substituents on ring $\mathbf{A}$, (b) the nature of the ring $\mathbf{C}$ substituents, (c) position of the ring $\mathbf{C}$ substituents, and (d) the nature of polycyclic lactone. First, with respect to the substituents on ring A (Figure 4), in general, the substitution of the $\mathrm{H}$ for a methoxy group presents a decreasing of activity (see Table 2, 17a and $\mathbf{1 7 b}$ versus $\mathbf{5 a}$ and $\mathbf{5 b}$ ).

A parallel examination of compounds $\mathbf{1}$ and $\mathbf{2} \mathbf{a}-\mathbf{8 a}$, which have alkyl substituents on ring $\mathbf{C}$, shows that the cytotoxic activity is best for compound $\mathbf{5 a}$, which possesses a pentyl chain on the $\mathrm{C}-11$ and a methyl group on the $\mathrm{C}-4$. The introduction of substituents with less than four $\mathrm{C}$ or more than six $\mathrm{C}$ at the C-11 position confers a decrease of cytotoxic activity. Compound 5a, bearing a pentyl group on the $\mathrm{C}-11$, showed an increase in the potency relative to the one bearing a propyl group substituent 3a. The butyl homologue 4a was less potent than 5a and more potent than the new analogue compounds bearing a lower chain $\mathbf{3 a}, \mathbf{2 a}$, and $\mathbf{1}$.

It is important to point out that the side chain at C-11 (the same side of the lactone carbonyl) confers greater activity for the inhibition of cell proliferation $(\mathbf{4 a}, \mathbf{5 a}$, and $\mathbf{6 a} v \mathrm{vs} \mathbf{4 b}, \mathbf{5} \mathbf{b}$, and $\mathbf{6 b}$ ). Thus, in general, compounds with the alkyl chain on the $\mathrm{C}-11$ (series $a$ ) are more active than compounds with this chain on the $\mathrm{C}-4$ (series $b$ ).

The lactones 5a and $6 \mathbf{a}$ showed similar cytotoxic activity, 
Scheme 3. Preparation of Lactones $\mathbf{1 4 - 1 6}$ and 19

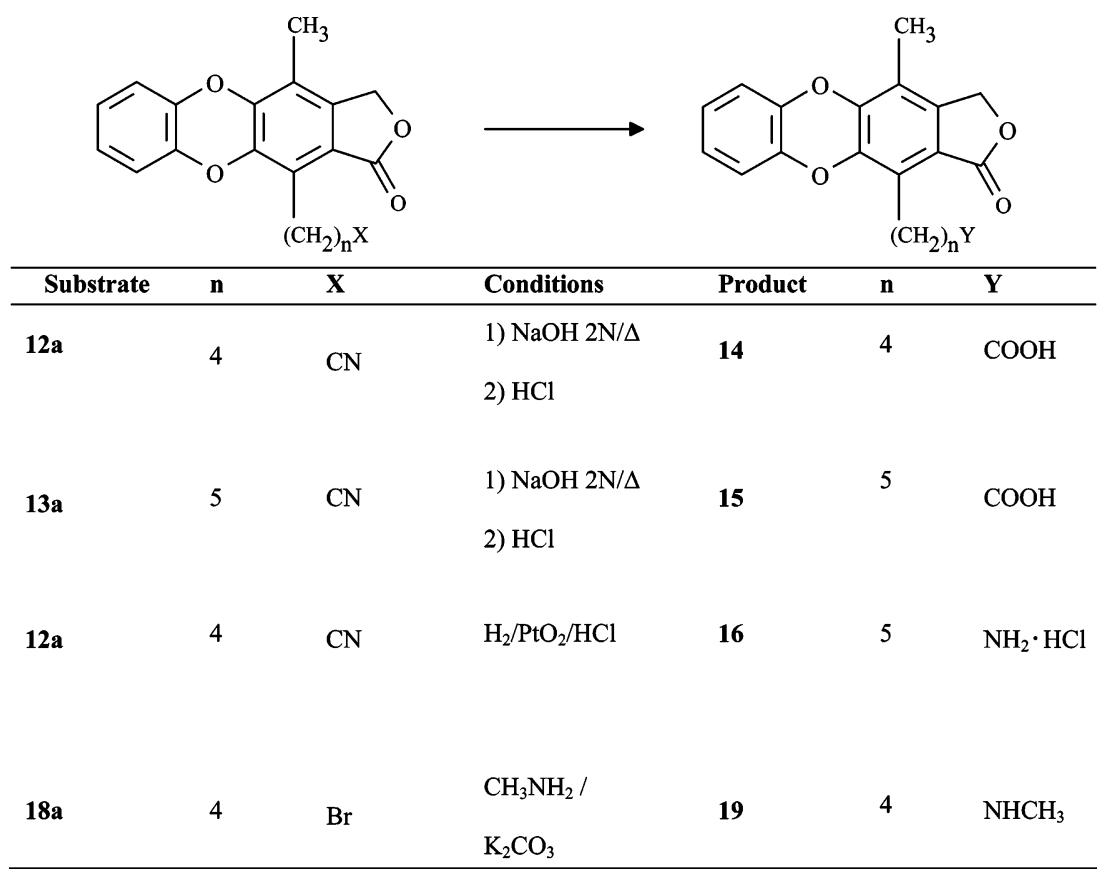

Table 1. Lewis Acids Tested as Catalyst in the Diels-Alder Reaction of $\mathbf{4 8}^{a}$

\begin{tabular}{|c|c|c|c|c|c|c|c|}
\hline catalyst & & $\mathrm{SiO}_{2}$ & $\mathrm{MgBr}_{2}{ }^{b}$ & $\mathrm{BF}_{3} \cdot\left(\mathrm{CH}_{3} \mathrm{CH}_{2}\right)_{2} \mathrm{O}^{b}$ & $\mathrm{SnCl}_{4}{ }^{b}$ & $\mathrm{TiCl}_{4}^{b}$ & $\mathrm{Yb}\left(\mathrm{CF}_{3} \mathrm{SO}_{3}\right)_{3}{ }^{b}$ \\
\hline yield $(\%)$ & $0 *$ & $0^{*}$ & $5^{*}$ & $40 * *$ & $15 * *$ & $16^{* *}$ & $77 * * *$ \\
\hline
\end{tabular}

${ }^{a}$ The symbol $*$ designates a time of reaction $=12 \mathrm{~h} ; * *$ designates a time of reaction $=10 \mathrm{~min}$; and $* * *$ designates a time of reaction $=4 \mathrm{~h} .{ }^{b}$ Yields of isolated products.

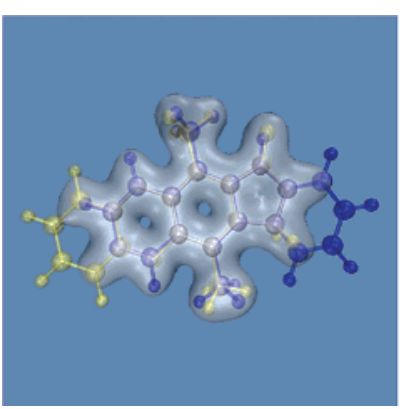

Figure 1. Electron density alignment of 4,11-dimethyl-1-oxo-3(H)isobenzofuro[5,6- $b][1,4]$ benzodioxine and ellipticine, in yellow and blue, respectively. The largest $\rho_{\mathrm{CP}}(\mathbf{r})$ isocontour surface is displayed at $0.001 e^{2} a_{0}^{-6}$.

but 6 a was slightly more specific in disturbing cell cycle $\left(\mathrm{G}_{2} /\right.$ M, $8 \mathrm{~N}, 86 \%, 5 \mu \mathrm{M})$ than $\mathbf{5 a}$.

Particularly remarkable was the considerable cytotoxic activity of $\mathbf{4 a}$ and 5a on HT-29 human colon line $\left(\mathrm{IC}_{50}=5.8 \times\right.$ $10^{-7} \mathrm{M}$ and $\mathrm{IC}_{50}=1.2 \times 10^{-7} \mathrm{M}$, respectively) and also the high selectivity for the $\mathrm{G}_{2}$ phase of the cell cycle (induced the accumulation of $67 \%$ of cells at the $\mathrm{G}_{2} / \mathrm{M}$ phase by $4 \mathbf{a}$ and $80 \%$ by $\mathbf{5 a})$.

On the other hand, the introduction of branched substituents at the alkyl chain on C-11 decreases the activity by more than 10 times (see 5a vs 10a).

The activity appears closely dependent on the number of methylenes in the side chain and on the nature of the substituents of this chain.

Until now, the C-4 and/or C-11 substituents had homologous alkyl chains, but it is interesting to study that the introduction of three distinct functions on the side chain is related to obtaining complementary results. It may be seen that $\mathbf{1 3 a}$ exhibits greater

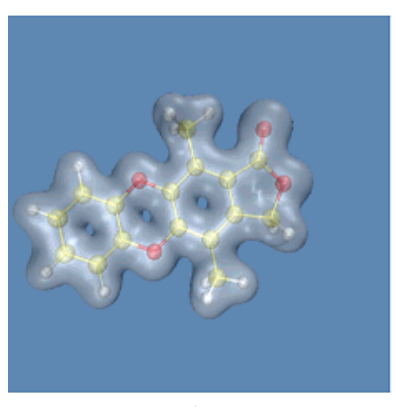

a

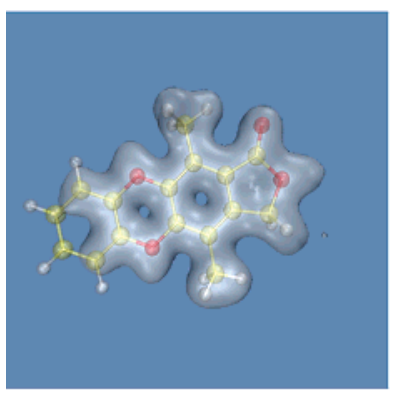

c

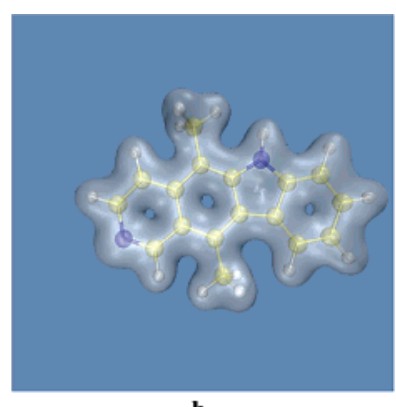

b

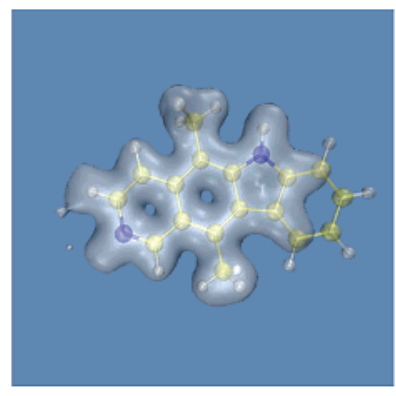

d
Figure 2. Electron density isocontour surfaces at $0.03 e a_{0}^{-3}$, and ball and stick representation of (a) 4,11-dimethyl-1-oxo-3(H)-isobenzofuro[5,6- $b][1,4]$ benzodioxine and (b) ellipticine. The corresponding largest $\rho_{\mathrm{CP}}(\mathbf{r})$ isocontour is displayed in (c) and (d), respectively, at $0.001 e^{2}$ $a_{0}^{-6}$.

activity according to the results of the nonfunctionalized chain compounds (3-fold more activity than $\mathbf{6 a}$ and $\mathbf{5 a}$ against leukemia L1210 and more activity than 6a on HT-29 line cells). Whereas the introduction of the nitrile group on the side chain increases the activity (compare 13a and 6a), the introduction of some hydrophilic function as carboxylic acid (15) or primary 


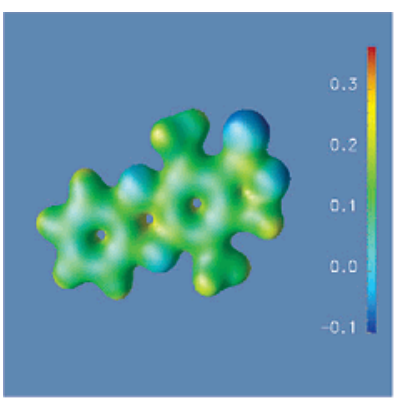

a

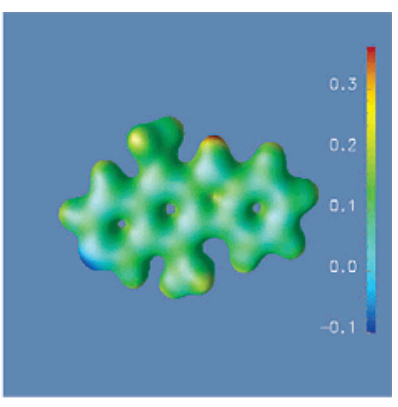

b
Figure 3. Electron density isocontour surface of (a) 4,11-dimethyl1-oxo-3 $(H)$-isobenzofuro[5,6- $b][1,4]$ benzodioxine and (b) ellipticine at 0.03 e $a_{0}^{-3}$, mapped with the electrostatic potential values.

amine on the $\mathrm{C}$-11 chain (16) produces a 15 -fold reduction of the activity on the colon HT-29 cell line and a 2-fold reduction on the leukemia L1210 cells, with respect to the unsubstituted compound $\mathbf{6 a}$.

The cyano alkyl 12a displayed less cytotoxicity than 5a. The hexyl derivative $\mathbf{6 a}$, enhances the activity due to the addition of the cyano group (compare $\mathbf{6 a}$ and 13a). Comparison of the analogues $\mathbf{1 6}$ and $\mathbf{1 9}$ suggested that a secondary amine was more active than a primary amine.

Generally, these compounds were globally more potent on the colon HT-29 cell line than on the leukemia L1210 cells (15-fold in the case of 5a and 4.5-fold in the case of 13a and 19). Compounds $4 \mathbf{a}-7 \mathbf{a}, 12 \mathrm{a}, 13 \mathrm{a}, \mathbf{1 6}$, and 19 showed selectivity toward colon HT-29 cell lines, and only 5b, 10a, 11, and 14 showed little selectivity toward leukaemia L1210 cell lines.

Particularly remarkable was the lack of activity obtained for the thiolactone 11a (9- and 90-fold less activity than the lactone 6a on L1210 and on colon HT-29 cell line, respectively).

Compound 9 has two long and flexible side chains at C-4 and $\mathrm{C}-11$ of the tetracyclic lactone, which potentially could provide hindrance and make difficult the binding with the site of action. This fact could explain the inactivity of this compound.

On the other hand, the simplified lactone 35, which bears important structural modifications on the proposed skeleton of this series, is inactive. The inactivity may be due to an insufficient structural similarity to the tetracyclic lactones, such as 5a. The compounds 13a and 5a were the most promising, and 6a was of particular interest because of its marked activity in vitro against leukemia L1210 and against colon HT-29 cell line. Compound 13a exhibited potent activity against both tumor cell lines and, in particular, its cytotoxic effect against HT-29 $\left(\mathrm{IC}_{50}=0.12 \mu \mathrm{M}\right)$ was greater than that of adriamycin $\left(\mathrm{IC}_{50}=\right.$ $0.48 \mu \mathrm{M})$ or ellipticine $\left(\mathrm{IC}_{50}=14.9 \mu \mathrm{M}\right)$.

The favorable influence on cytotoxic activity of the presence of a lipophilic alkyl chain was not mentioned before in antitumor studies. Instead, the introduction of polar chains that facilitate the solubility and also the biological interactions are better known.

The compound 6 a induced the accumulation of $86 \%$ of L1210 cells in the $\mathrm{G}_{2} / \mathrm{M}, 8 \mathrm{~N}$ phase.

In regard to the amino functionalized derivatives, the most active was the secondary amine 19 (5-fold more potent than the primary amine $\mathbf{1 6}$ on the L1210 cells and 10-fold more potent on HT-29 cells).

The bulk of the methoxy group could explain the fact that the substituted compounds (17a and 17b) are inactive. In other works related to the ellipticine, compounds with a methoxy group on the aromatic ring $\mathbf{A}$ showed more cytotoxicity than the unsubstituted parent. ${ }^{18}$

Some of these compounds (4a, 5a, 5b, 6a, and 19) could block the cell cycle progression of L1210 cells in the $G_{2} / M$ phase in the same pattern as shown by adriamycin, while compounds 7a and 13a showed an affect on the $8 \mathrm{~N}$ phase.

In conclusion, a series of tetracyclic lactones were synthesized and evaluated in vitro against the leukemia L1210 cell line, colon HT-29 cell line, and also the cycle inhibition studied (Table 2). The presence of an alkyl chain at position C-11 appears as an important structural requirement to observe potent cytotoxic activity in this series. The decrease of cytotoxicity observed by lengthening and shortening the alkyl chain at the C-11 position of the tetracyclic system reveals that the optimal length was five $\mathrm{C}$ (see Figure 5). The presence of a cyano, carboxylic acid, or amino group on the side chain has a marked influence on the activity.

Considering substitutions on the side chain at the C-11, it appeared, as indicated in Table 2, that weak structural modifications were responsible for the activity variation and that this series and the ellipticine series are not comparable in terms of structure-activity relationships. ${ }^{18}$

Despite the interesting activity of lactones, the mechanism of their action at both cellular and molecular level has not yet been clearly established. Considering that the main accepted mode of action for ellipticine is based on the interaction with the enzyme topoisomerase II in terms of stabilization of the cleavage complex, which is formed between DNA and topoisomerase II during a particular stage of the cell cycle, $\mathbf{4 a}$ and 13a were examined for their ability to facilitate the formation of a cleavage complex as an indication of the inhibition of topoisomerase II. ${ }^{19}$ These compounds did not show inhibition of topoisomerase II consistent with their cytotoxicity.

Among all of these compounds, only the compound $\mathbf{4 a}$ (NSC: $707690-\mathrm{M} / 1$ ) was selected by the NCI for testing in vitro against 60 cells lines of the NCI anticancer drug screen derived from eight cancer types (leukemia, non small cell lung cancer, small cell lung cancer, colon cancer, CNS cancer, melanoma, ovarian cancer, and renal cancer). The $\mathrm{GI}_{50}\left(\mathrm{GI}_{50}\right.$ values are the concentrations corresponding to $50 \%$ growth inhibition, and are averages of at least two determinations) and $\mathrm{LC}_{50}$ (a concentration at which $50 \%$ of the cells were killed in a $96 \mathrm{~h}$ assay) values obtained with selected cell lines are summarized in Table 3. For the most part, there are no differences between $\log \mathrm{GI}_{50}$ or $\mathrm{LC}_{50}$ values for the cell lines tested, only a small CNS and colon selectivity at the levels for growth inhibition was displayed. However, the cytotoxicity remains at the micromolar level and confirms the results provided by the Institut de Recherches Servier.

Results from COMPARE searches often provide insight into the mechanism of action of new compounds. ${ }^{20}$ COMPARE analysis of $\mathbf{4 a}$ and standard anticancer agent database of the NCI anticancer drug screen using the determination of Pearson correlation coefficient found no significant correlation $(P>100)$ between the $\mathrm{IC}_{50}$ of the $\mathbf{4 a}$ and the $\mathrm{IC}_{50}$ of known topoisomerase II inhibitors (9-hydroxy-2-methylellipticinium NSC, 264137; amsacrine NSC, 249992; etoposide NSC, 141540; adriamycin (doxorubicin) NSC, 123127; mitoxantrone NSC, 301739). ${ }^{17}$

The molecular target of these compounds is not known, and the study was continued by making additional biological studies. The capacity of compounds $\mathbf{4 a}$ and $\mathbf{5 a}$ to bind to DNA and to inhibit human DNA topoisomerases I and $\mathrm{II}^{21}$ was investigated. However, no significant effect was observed compared with the reference compounds camptothecin or etoposide. These com- 


\section{Compound $\quad \mathrm{IC}_{50} \mathrm{L1210}(\mu \mathrm{M}) \quad \mathrm{IC}_{50} \mathrm{HT}-29(\mu \mathrm{M}) \quad$ Cycle $(\mathrm{L1210})^{\mathrm{b}}$}

Compound

$\mathrm{IC}_{50} \mathrm{L1210}(\mu \mathrm{M}) \quad \mathrm{IC}_{50} \mathrm{HT}-29(\mu \mathrm{M})$

Cycle (L1210)

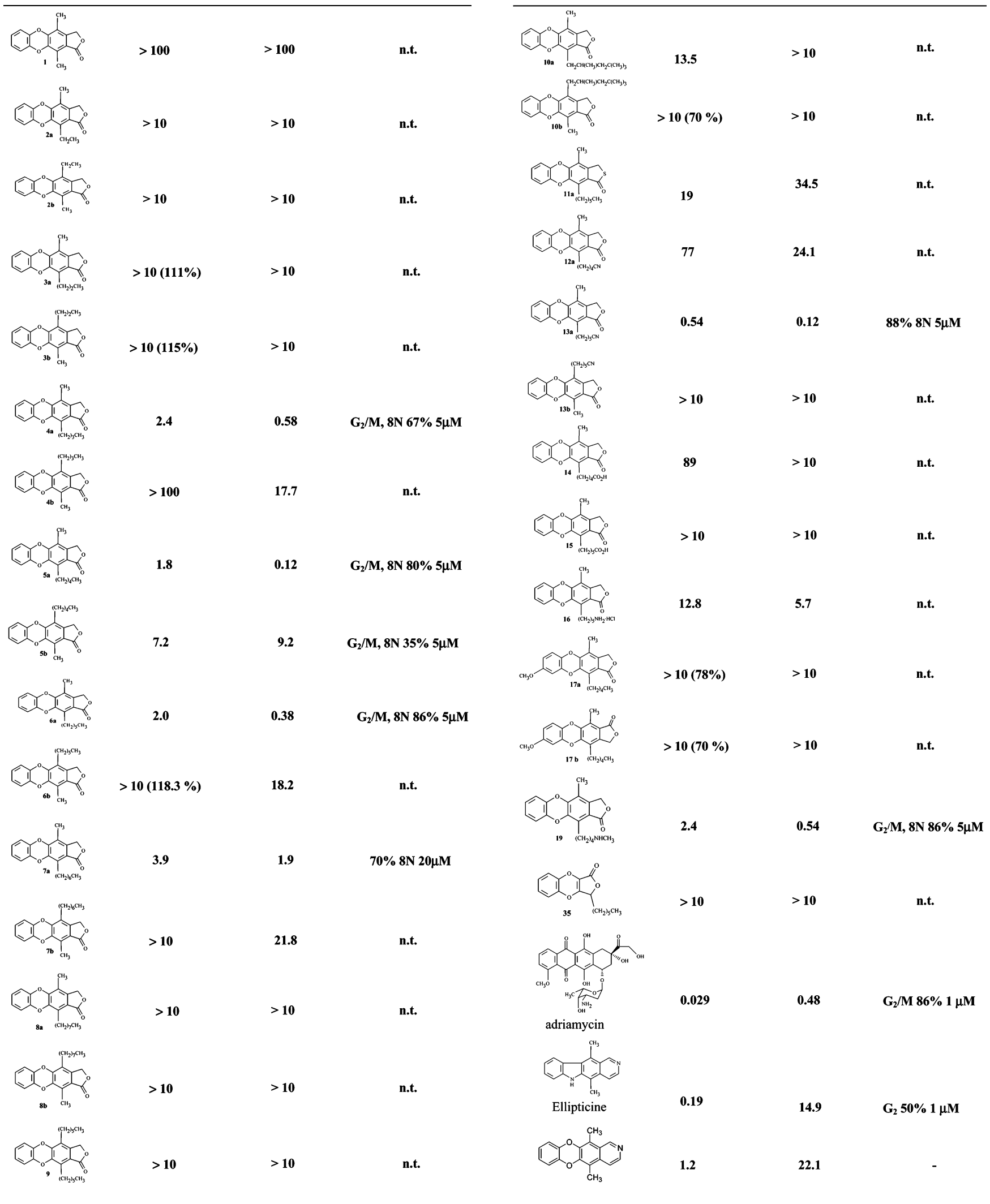

\footnotetext{
${ }^{a}$ Inhibition of L1210 and HT-29 cell proliferation measured by in vitro biological assay. $\mathrm{IC}_{50}$ values are mean concentrations that inhibit growth by $50 \%$ $\left(\mathrm{IC}_{50}\right.$ values are the average of at least four determinations in triplicate obtained in independent experiments. Variation between replicates was less than 5\%). ${ }^{b}$ Percentage of L1210 cells arrested in cell cycle phase after $24 \mathrm{~h}$ of exposure to the indicated concentration of problem compound. n.t. $=$ not tested (considered not interesting due to poor activity on L1210 cell lines).
} 


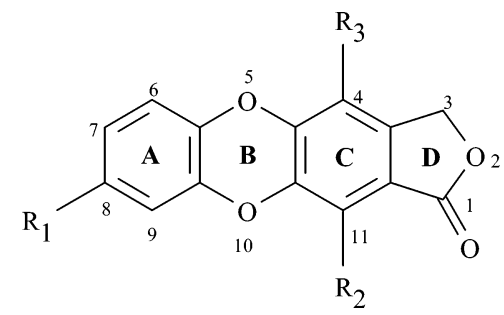

Figure 4. General structure of series $a$ and $b$ of lactones.

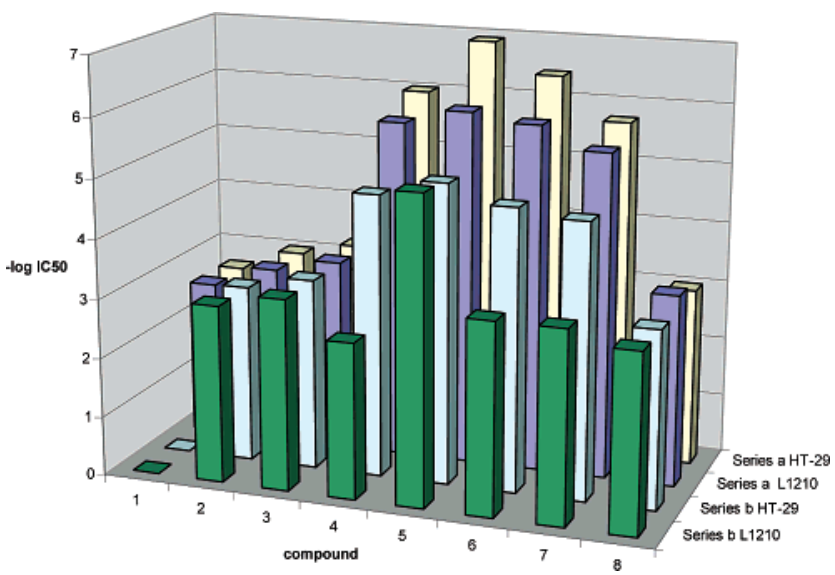

Figure 5. Plots $-\log _{10}\left(\mathrm{IC}_{50}\right)$ versus cancer type (L1210, and HT-29) for compounds $\mathbf{1}, \mathbf{2} \mathbf{a}-\mathbf{8 a}$, and $\mathbf{2 b}-\mathbf{8 b}$.

pounds have no effect on the melting temperature of the DNA double helix, be it with calf thymus ( $42 \%$ GC) or with the polynucleotide poly $(\mathrm{dAT})_{2}$.

DNA sequence recognition was studied by DNase I footprinting. ${ }^{22}$ No marked modification of the absorption spectra of the compounds was observed upon addition of DNA, and no specific binding site was detected in the DNase I footprinting assay, indicating also that these molecules do not appreciably bind to DNA.

In parallel, a plasmid supercoiled DNA (pKMp27 DNA) was used to study the relaxation and cleavage of DNA by purified topoisomerases I and II. ${ }^{23}$ Here again, we found no effect of compounds $\mathbf{4 a}$ and $\mathbf{5 a}$ in these biochemical assays. Moreover, compounds $\mathbf{4 a}$ and $\mathbf{1 3}$ were tested using another native supercoiled DNA (pYRG DNA), and the results were inconclusive (no DNA binding). ${ }^{24}$ These compounds do not stimulate DNA cleavage by the enzymes and do not interfere with the poisoning effects of camptothecin on topoisomerase I or etoposide on topoisomerase II. The effect of no detectable binding to DNA, the absence of inhibition of either topoisomerase I or topoisomerase II, and the negative response to the DNA relaxation test confirm the results previously obtained from COMPARE analysis.

These compounds do not correlate with any known compound in the National Cancer Institute's data base, suggesting a unique mechanism of action.

The structure-activity relationships allowed refining the structural requirements of this series of dioxygenated compounds. Lactone appears essential for cytotoxicity, and its substitution by a thiolactone prevents us from obtaining the same activity. On the other hand, if we consider the side chain position and the nature of its substituents, it appears that the substituent on the $\mathrm{C}-11$ position leads to an increase of the relative activity compared with C-4 substitution. Finally, this SAR study indicated that the best substituent must possess a linear alkyl chain of $5 \mathrm{C}(\mathbf{5 a})$ or a linear alkyl chain with a cyano group in position 5 (13a). These results strengthen our purpose of performing new pharmacological investigations to elucidate the mechanism of action. These biological results corroborate the observation that a chemical modification of the structure framework may result in a profound impact in the biological activity.

In summary, several new synthetic tetracyclic lactones described in this paper have antitumor activity at the micromolar level. The cytotoxic activity is quantitatively comparable to the natural ellipticine, but they show a different mechanism of action. Likewise, the main structural features influencing the antitumor activity are different from the ellipticine series. Among the tested compounds, 4a, 5a, and 13a are considered promising leads for further structural modifications, perhaps guided by the valuable information obtainable from detailed analysis of theoretical studies.

The results of this study, we believe, will provide useful information for the design of novel class of cytotoxic agents.

\section{Experimental Section}

Chemistry. Melting points were obtained on a MFB-595010M Gallenkamp apparatus in open capillary tubes and are uncorrected. IR spectra were obtained using a FTIR Perkin-Elmer 1600 infrared spectrophotometer. Only noteworthy IR absorptions are listed ( $v$ expressed in $\left.\mathrm{cm}^{-1}\right) .{ }^{1} \mathrm{H}$ and ${ }^{13} \mathrm{C}$ NMR spectra were recorded on a Varian Gemini-200 (200 and 50.3 MHz, respectively) or Varian Gemini-300 (300 and 75.5 MHz) instrument using $\mathrm{CDCl}_{3}$ as solvent with tetramethylsilane as internal standard or $\left(\mathrm{CD}_{3}\right)_{2} \mathrm{CO}$. Other ${ }^{1} \mathrm{H}$ NMR spectra and heterocorrelation ${ }^{1} \mathrm{H}-{ }^{13} \mathrm{C}$ (HMQC and $\mathrm{HMBC}$ ) experiments were recorded on a Varian VXR-500 (500 MHz). Mass spectra were recorded on a Hewlett-Packard 5988-A. Column chromatography was performed with silica gel (E. Merck, 70$230 \mathrm{mesh}$ ). Reactions were monitored by TLC using $0.25 \mathrm{~mm}$ silica gel F-254 (E. Merck). Microanalysis was determined on a Carlo Erba-1106 analyzer. All reagents were of commercial quality or were purified before use. Organic solvents were of analytical grade or were purified by standard procedures. Commercial products were obtained from Sigma-Aldrich.

Preparation of Lactones (1-13a, 2b-13b, 17a-18a, 17b18b) from Diels-Alder Cycloadditions of the Furans (48-62). General Procedure. 2(5H)-Furanone $63(1.5 \mathrm{mmols})$ or $2(5 H)$ thiofuranone 64 (1.5 mmols) and a catalytic amount of ytterbium triflate were added to the corresponding diene $(1 \mathrm{mmol})$ without solvent at room temperature.

The mixture was stirred in a hermetically closed flask on a preheated bath at $90-100{ }^{\circ} \mathrm{C}$ for $4 \mathrm{~h}$. Purification of the crude product by silica gel column chromatography, using hexane/ethyl acetate as eluent, allowed us to obtain two positional isomers that were accurately identified as $a$ or $b$.

4,11-Dimethyl-1-oxo-3(H)-isobenzofuro[5,6- $b][1,4]$ benzodioxine (1). Starting from the diene $48(523 \mathrm{mg}, 2.59 \mathrm{mmol})$ and the lactone 63, and following the general procedure described above for the preparation of lactones, we obtained the lactone 1 (535 mg, $1.99 \mathrm{mmol})$. The crude product was purified by silica gel column chromatography, using hexane/ethyl acetate $95 / 5$ as eluent, giving the lactone as an oil in $77 \%$ of yield. Anal. $\left(\mathrm{C}_{16} \mathrm{H}_{12} \mathrm{O}_{4}\right) \mathrm{C}, \mathrm{H}$.

11-Ethyl-4-methyl-1-oxo-3 $(H)$-isobenzofuro[5,6- $b][1,4]$ benzodioxine (2a). Starting from the diene $49(621 \mathrm{mg}, 2.87 \mathrm{mmol})$ and the lactone 63, and following the general procedure described above for the preparation of lactones, we obtained the lactone 2a. Purification of the crude product by silica gel column chromatography, using hexane/ethyl acetate $95 / 5$ as eluent, gave the lactone as a white solid in $32 \%$ of yield. When hexane/ethyl acetate 96/4 mixtures were used as eluent, the isomer $\mathbf{2 b}$ was obtained in $44 \%$ yield. For 2a: mp 205-208 ${ }^{\circ} \mathrm{C}$ (hexane/ethyl acetate). Anal. $\left(\mathrm{C}_{17} \mathrm{H}_{14} \mathrm{O}_{4}\right) \mathrm{C}, \mathrm{H}$.

4-Ethyl-11-methyl-1-oxo-3 $(H)$-isobenzofuro[5,6- $b][1,4]$ benzodioxine (2b). Compound $\mathbf{2 b}$ was obtained as a white solid, $44 \%$ yield; mp $185-188{ }^{\circ} \mathrm{C}$ (hexane /ethyl acetate). Anal. $\left(\mathrm{C}_{17} \mathrm{H}_{14} \mathrm{O}_{4}\right) \mathrm{C}, \mathrm{H}$. 
4-Methyl-11-propyl-1-oxo-3(H)-isobenzofuro[5,6- $b]^{1,4}$ benzodioxine (3a). Starting from the diene $\mathbf{5 0}(681 \mathrm{mg}, 2.96 \mathrm{mmol})$ and the lactone $\mathbf{6 3}$, and following the general procedure described above for the preparation of lactones, we obtained the lactone 3a. Purification of the crude product by silica gel column chromatography, using hexane/ethyl acetate $96 / 4$ as eluent, gave the lactone as a white solid in $33 \%$ yield. When hexane/ethyl acetate $97 / 3$ mixtures were used as eluent, the isomer $\mathbf{3 b}(378 \mathrm{mg}, 1.27 \mathrm{mmol})$ was obtained as a white solid in $45 \%$ yield. For 3a: mp 199-202 ${ }^{\circ} \mathrm{C}$ (hexane/ethyl acetate). Anal. $\left(\mathrm{C}_{18} \mathrm{H}_{16} \mathrm{O}_{4}\right) \mathrm{C}, \mathrm{H}$.

11-Methyl-4-propyl-1-oxo-3 $(H)$-isobenzofuro[5,6-b][1,4]benzodioxine (3b). Mp 191-194 ${ }^{\circ} \mathrm{C}$ (hexane /ethyl acetate). Anal. $\left(\mathrm{C}_{18} \mathrm{H}_{16} \mathrm{O}_{4}\right) \mathrm{C}, \mathrm{H}$.

11-Butyl-4-methyl-1-oxo-3(H)-isobenzofuro[5,6- $b][1,4]$ benzodioxine (4a). Starting from the diene $\mathbf{5 1}(695 \mathrm{mg}, 2.84 \mathrm{mmol})$ and the lactone 63, and following the general procedure described above for the preparation of lactones, we obtained the lactone $\mathbf{4 a}$. Purification of the crude product by silica gel column chromatography, using hexane/ethyl acetate $97 / 3$ as eluent, gave the lactone as a white solid in $31 \%$ of yield. When the same eluent was used, the isomer $\mathbf{4 b}$ (380 mg, $1.2 \mathrm{mmol})$ was obtained in $43 \%$ yield; $\mathrm{mp}$ $122-125{ }^{\circ} \mathrm{C}$ (hexane/ethyl acetate). Anal. $\left(\mathrm{C}_{19} \mathrm{H}_{18} \mathrm{O}_{4}\right) \mathrm{C}, \mathrm{H}$.

4-Butyl-11-methyl-1-oxo-3 $(H)$-isobenzofuro $[5,6-b][1,4]$ benzodioxine (4b). Mp $153-155{ }^{\circ} \mathrm{C}$ (hexane /ethyl acetate). Anal. $\left(\mathrm{C}_{19} \mathrm{H}_{18} \mathrm{O}_{4}\right) \mathrm{C}, \mathrm{H}$.

4-Methyl-11-pentyl-1-oxo-3 $(H)$-isobenzofuro[5,6-b][1,4]benzodioxine (5a). Starting from the diene $\mathbf{5 2}(598 \mathrm{mg}, 2.32 \mathrm{mmol})$ and the lactone $\mathbf{6 3}$, and following the general procedure described above for the preparation of lactones, we obtained the lactone 5a. Purification of the crude product by silica gel column chromatography, using hexane/ethyl acetate $98 / 2$ as eluent, gave the lactone as a white solid in $28 \%$ yield $(256 \mathrm{mg}, 0.77 \mathrm{mmol})$. When hexane/ ethyl acetate $99 / 1$ was used as eluent, the isomer $\mathbf{5 b}$ was obtained in $45 \%$ yield; $\mathrm{mp} 108-110{ }^{\circ} \mathrm{C}$ (hexane/ethyl acetate). Anal. $\left(\mathrm{C}_{20} \mathrm{H}_{20} \mathrm{O}_{4}\right) \mathrm{C}, \mathrm{H}$.

11-Methyl-4-pentyl-1-oxo-3 $(H)$-isobenzofuro[5,6- $b][1,4]$ benzodioxine (5b). Mp 145-146 ${ }^{\circ} \mathrm{C}$ (hexane/ethyl acetate). Anal. $\left(\mathrm{C}_{20} \mathrm{H}_{20} \mathrm{O}_{4}\right) \mathrm{C}, \mathrm{H}$.

11-Hexyl-4-methyl-1-oxo-3(H)-isobenzofuro[5,6-b][1,4]benzodioxine (6a). Starting from the diene $\mathbf{5 3}(603 \mathrm{mg}, 2.21 \mathrm{mmol})$ and the lactone 63, and following the general procedure described above for the preparation of lactones, we obtained the lactone $\mathbf{6 a}$. Purification of the crude product by silica gel column chromatography, using hexane/ethyl acetate $98 / 2$ as eluent, gave the lactone as a white solid in $36 \%$ of yield. When the same eluent was used, the isomer $6 \mathbf{b}(292 \mathrm{mg}, 0.86 \mathrm{mmol})$ was obtained in $39 \%$ yield; mp $131-133{ }^{\circ} \mathrm{C}$ (hexane/ethyl acetate). Anal. $\left(\mathrm{C}_{21} \mathrm{H}_{22} \mathrm{O}_{4}\right) \mathrm{C}, \mathrm{H}$.

4-Hexyl-11-methyl-1-oxo-3 $(H)$-isobenzofuro[5,6- $b][1,4]$ benzodioxine (6b). Mp 149-150 ${ }^{\circ} \mathrm{C}$ (hexane/ ethyl acetate). Anal. $\left(\mathrm{C}_{21} \mathrm{H}_{22} \mathrm{O}_{4}\right) \mathrm{C}, \mathrm{H}$.

11-Heptyl-4-methyl-1-oxo-3(H)-isobenzofuro[5,6-b][1,4]benzodioxine (7a). Starting from the diene $55(627 \mathrm{mg}, 2.19 \mathrm{mmol})$ and the lactone 63, and following the general procedure described above for the preparation of lactones, we obtained the lactone $7 \mathbf{a}$. Purification of the crude product by silica gel column chromatography, using hexane/ethyl acetate 98/2 as eluent, gave the lactone as a white solid in $29 \%$ of yield. When the same eluent was used, the isomer $7 \mathbf{b}$ (302 $\mathrm{mg}, 0.86 \mathrm{mmol}$ ) was obtained as a white solid in $39 \%$ yield; $\mathrm{mp} 103-104{ }^{\circ} \mathrm{C}$ (hexane/ethyl acetate). Anal. $\left(\mathrm{C}_{22} \mathrm{H}_{24} \mathrm{O}_{4}\right) \mathrm{C}, \mathrm{H}$.

4-Heptyl-11-methyl-1-oxo-3 $(H)$-isobenzofuro[5,6- $b][1,4]$ benzodioxine (7b). Mp 153-154 ${ }^{\circ} \mathrm{C}$ (hexane/ ethyl acetate). Anal. $\left(\mathrm{C}_{22} \mathrm{H}_{24} \mathrm{O}_{4}\right) \mathrm{C}, \mathrm{H}$.

4-Methyl-11-octyl-1-oxo-3(H)-isobenzofuro[5,6- $b][1,4]$ benzodioxine (8a). Starting from the diene $\mathbf{5 6}(598 \mathrm{mg}, 1.99 \mathrm{mmol})$ and the lactone $\mathbf{6 3}$, and following the general procedure described above for the preparation of lactones, we obtained the lactone 8a. Purification of the crude product by silica gel column chromatography, using hexane/ethyl acetate $98 / 2$ as eluent, gave the lactone as a white solid in $27 \%$ of yield. When hexane/ethyl acetate 99/1 was used, the isomer $\mathbf{8 b}(321 \mathrm{mg}, 0.88 \mathrm{mmol})$ was obtained as a white solid in $44 \%$ yield; $\mathrm{mp} 84-86^{\circ} \mathrm{C}$ (hexane/ethyl acetate). Anal. $\left(\mathrm{C}_{23} \mathrm{H}_{26} \mathrm{O}_{4}\right) \mathrm{C}, \mathrm{H}$.

11-Methyl-4-octyl-1-oxo-3 $(H)$-isobenzofuro $[5,6-b][1,4]$ benzodioxine (8b). Mp $137-138{ }^{\circ} \mathrm{C}$ (hexane/ ethyl acetate). Anal. $\left(\mathrm{C}_{23} \mathrm{H}_{26} \mathrm{O}_{4}\right) \mathrm{C}, \mathrm{H}$.

4,11-Dihexyl-1-oxo-3 $(H)$-isobenzofuro[5,6- $b][1,4]$ benzodioxine (9). Starting from the diene $54(721 \mathrm{mg}, 2.11 \mathrm{mmol})$ and the lactone 63, and following the general procedure described above for the preparation of lactones, we obtained the lactone 9. Purification of the crude product by silica gel column chromatography, using hexane/ethyl acetate 99/1 as eluent, gave the lactone as a white solid in $73 \%$ of yield; mp $115-117^{\circ} \mathrm{C}$ (hexane/ethyl acetate). Anal. $\left(\mathrm{C}_{26} \mathrm{H}_{32} \mathrm{O}_{4}\right) \mathrm{C}, \mathrm{H}$.

4-Methyl-11-(2,4,4-trimethylpentyl)-1-oxo-3(H)-isobenzofuro[5,6-b][1,4]benzodioxine (10a). Starting from the diene 57 (659 $\mathrm{mg}, 2.01 \mathrm{mmol}$ ) and the lactone $\mathbf{6 3}$, and following the general procedure described above for the preparation of lactones, we obtained the lactone 10a. Purification of the crude product by silica gel column chromatography, using hexane/ethyl acetate $98 / 2$ as eluent, gave the lactone as a white solid in $29 \%$ of yield. When hexane/ethyl acetate 99/1 was used, the isomer 10b (356 mg, 0.90 mmol) was obtained as a white solid in $45 \%$ yield; $\mathrm{mp} 182-183$ ${ }^{\circ} \mathrm{C}$ (hexane/ethyl acetate). Anal. $\left(\mathrm{C}_{23} \mathrm{H}_{26} \mathrm{O}_{4}\right) \mathrm{C}, \mathrm{H}$.

11-Methyl-4-(2,4,4-trimethylpentyl)-1-oxo-3(H)-isobenzofuro[5,6-b][1,4]benzodioxine (10b). Mp $161-162{ }^{\circ} \mathrm{C}$ (hexane/ethyl acetate). Anal. $\left(\mathrm{C}_{23} \mathrm{H}_{26} \mathrm{O}_{4}\right) \mathrm{C}, \mathrm{H}$.

11-Hexyl-4-methyl-1-oxo-3 $(H)$-isobenzothiofeno[5,6- $b][1,4]-$ benzodioxine (11a). Starting from the diene $\mathbf{5 3}(700 \mathrm{mg}, 2.57$ $\mathrm{mmol}$ ) and the thiolactone $\mathbf{6 4}$, and following the general procedure described above for the preparation of lactones, we obtained the lactone 11a. Purification of the crude product by silica gel column chromatography, using hexane/ethyl acetate $80 / 20$ as eluent, gave the lactone as a white solid in $36 \%$ of yield. When hexane/ethyl acetate 70/30 was used, the isomer $\mathbf{1 1 b}(382 \mathrm{mg}, 1.06 \mathrm{mmol})$ was obtained as a white solid in $42 \%$ yield; $\mathrm{mp} 126-129{ }^{\circ} \mathrm{C}$ (hexane/ ethyl acetate). Anal. $\left(\mathrm{C}_{21} \mathrm{H}_{22} \mathrm{O}_{3} \mathrm{~S}\right) \mathrm{C}, \mathrm{H}$.

4-Hexyl-11-methyl-1-oxo-3(H)-isobenzothiofeno[5,6-b][1,4]benzodioxine (11b). Mp $131-133{ }^{\circ} \mathrm{C}$ (hexane/ethyl acetate). Anal. $\left(\mathrm{C}_{21} \mathrm{H}_{22} \mathrm{O}_{3} \mathrm{~S}\right) \mathrm{C}, \mathrm{H}$.

11-(4-Cyanobutyl)-4-methyl-1-oxo-3(H)-isobenzofuro[5,6-b][1,4]benzodioxine (12a). Starting from the diene $\mathbf{5 8}(458 \mathrm{mg}, 1.70$ $\mathrm{mmol}$ ) and the lactone $\mathbf{6 3}$, and following the general procedure described above for the preparation of lactones, we obtained the lactone 12a. Purification of the crude product by silica gel column chromatography, using hexane/ethyl acetate 99/1 as eluent, gave the lactone as a white solid in $30 \%$ of yield. When hexane/ethyl acetate $98 / 2$ was used, the isomer $\mathbf{1 2 b}(245 \mathrm{mg}, 0.73 \mathrm{mmol}$ ) was obtained as a white solid in $43 \%$ yield; $\mathrm{mp} 169-171{ }^{\circ} \mathrm{C}$ (hexane/ ethyl acetate). Anal. $\left(\mathrm{C}_{20} \mathrm{H}_{17} \mathrm{NO}_{4}\right) \mathrm{C}, \mathrm{H}, \mathrm{N}$.

4-(4-Cyanobutyl)-11-methy-1-oxo-3(H)-isobenzofuro[5,6-b]$[\mathbf{1}, \mathbf{4}]$ benzodioxine (12b). Mp $178-181{ }^{\circ} \mathrm{C}$ (hexane/ethyl acetate). Anal. $\left(\mathrm{C}_{20} \mathrm{H}_{17} \mathrm{NO}_{4}\right) \mathrm{C}, \mathrm{H}, \mathrm{N}$.

11-(5-Cyanopentyl)-4-methyl-1-oxo-3(H)-isobenzofuro[5,6-b][1,4]benzodioxine (13a). Starting from the diene $\mathbf{5 9}(597 \mathrm{mg}, 2.11$ $\mathrm{mmol}$ ) and the lactone $\mathbf{6 3}$, and following the general procedure described above for the preparation of lactones, we obtained the lactone 13a. Purification of the crude product by silica gel column chromatography, using hexane/ethyl acetate 99/1 as eluent, gave the lactone as a white solid in $36 \%$ of yield. When hexane/ethyl acetate $98 / 2$ was used, the isomer $\mathbf{1 3 b}$ ( $318 \mathrm{mg}, 0.92 \mathrm{mmol}$ ) was obtained as a white solid in $43 \%$ yield; $\mathrm{mp} 110-113{ }^{\circ} \mathrm{C}$ (hexane/ ethyl acetate). Anal. $\left(\mathrm{C}_{21} \mathrm{H}_{19} \mathrm{NO}_{4}\right) \mathrm{C}, \mathrm{H}, \mathrm{N}$.

4-(5-Cyanopentyl)-11-methyl-1-oxo-3(H)-isobenzofuro[5,6- $b]$ [1,4]benzodioxine (13b). Mp $137-139{ }^{\circ} \mathrm{C}$ (hexane/ethyl acetate). Anal. $\left(\mathrm{C}_{21} \mathrm{H}_{19} \mathrm{NO}_{4}\right) \mathrm{C}, \mathrm{H}, \mathrm{N}$.

4-Methyl-8-methoxy-11-pentyl-1-oxo-3(H)-isobenzofuro[5,6b] 1,4$]$ benzodioxine (17a). Starting from the diene 61 (527 mg, $1.83 \mathrm{mmol}$ ) and the lactone $\mathbf{6 3}$, and following the general procedure described above for the preparation of lactones, we obtained the lactone 17a. Purification of the crude product by silica gel column chromatography, using hexane/ethyl acetate 99/1 as eluent, gave 
the lactone as a white solid in $34 \%$ of yield. When hexane/ethyl acetate $98 / 2$ was used, the isomer $\mathbf{1 7 b}$ (304 $\mathrm{mg}, 0.82 \mathrm{mmol}$ ) was obtained as a white solid in $45 \%$ yield; $\mathrm{mp} 137-139{ }^{\circ} \mathrm{C}$ (hexane/ ethyl acetate). Anal. $\left(\mathrm{C}_{21} \mathrm{H}_{22} \mathrm{O}_{5}\right) \mathrm{C}, \mathrm{H}$.

11-Methyl-7-methoxy-4-pentyl-1-oxo-3(H)-isobenzofuro[5,6b] $[\mathbf{1 , 4}]$ benzodioxine (17b). Mp $117-119^{\circ} \mathrm{C}$ (hexane/ethyl acetate). Anal. $\left(\mathrm{C}_{21} \mathrm{H}_{22} \mathrm{O}_{5}\right) \mathrm{C}, \mathrm{H}$.

4-Methyl-11-(4-bromobutyl)-1-oxo-3(H)-isobenzofuro[5,6-b][1,4]benzodioxine (18a). Starting from the diene 62 (602 mg, 1.86 $\mathrm{mmol}$ ) and the lactone $\mathbf{6 3}$, following the general procedure described above for the preparation of lactones, we obtained the tetracyclic compound 18a. Purification of the crude product by silica gel column chromatography, using hexane/ethyl acetate $90 / 10$ as eluent, gave the lactone as a white solid in $29 \%$ of yield. The isomer $\mathbf{1 8 b}$ (308 mg, $0.78 \mathrm{mmol}$ ) was obtained as a white solid in $43 \%$ yield using hexane/ethyl acetate $88 / 12$ as eluent; mp $146-148{ }^{\circ} \mathrm{C}$ (hexane/dichloromethane). Anal. $\left(\mathrm{C}_{19} \mathrm{H}_{17} \mathrm{BrO}_{4}\right) \mathrm{C}, \mathrm{H}$.

11-Methyl-4-(4-bromobutyl)-1-oxo-3(H)-isobenzofuro[5,6-b][1,4]benzodioxine (18b). Mp 160-162 ${ }^{\circ} \mathrm{C}$ (hexane/dichloromethane). Anal. $\left(\mathrm{C}_{19} \mathrm{H}_{17} \mathrm{BrO}_{4}\right) \mathrm{C}, \mathrm{H}$.

11-(4-Carboxybutyl)-4-methyl-1-oxo-3(H)-isobenzofuro[5,6b] $[1,4]$ benzodioxine (14). A solution containing the corresponding lactone (12a; $50 \mathrm{mg}, 0.15 \mathrm{mmol})$ in $2 \mathrm{~N} \mathrm{NaOH}(40 \mathrm{~mL})$ and methanol $(5 \mathrm{~mL})$ was refluxed for $2 \mathrm{~h}$. After $1 \mathrm{~N} \mathrm{HCl}$ was slowly added until $\mathrm{pH}=1$, and the suspension was filtered. The residue was dried to give the lactone $\mathbf{1 4}$ as a white solid (48 $\mathrm{mg}, 0.14$ mmol) in a $91 \%$ yield; $\mathrm{mp} 197-200{ }^{\circ} \mathrm{C}\left(\mathrm{H}_{2} \mathrm{O}\right)$. Anal. $\left(\mathrm{C}_{20} \mathrm{H}_{18} \mathrm{O}_{6}\right)$ $\mathrm{C}, \mathrm{H}$.

11-(5-Carboxypentyl)-4-methyl-1-oxo-3(H)-isobenzofuro[5,6b][1,4]benzodioxine (15). A solution containing the corresponding lactone (13a; $60 \mathrm{mg}, 0.17 \mathrm{mmol})$ in $2 \mathrm{~N} \mathrm{NaOH}(40 \mathrm{~mL})$ and methanol $(5 \mathrm{~mL})$ was refluxed for $2 \mathrm{~h} . \mathrm{HCl}(1 \mathrm{~N})$ was slowly added until $\mathrm{pH}=1$, and the suspension was filtered. The residue was dried to give the lactone $\mathbf{1 5}$ as a white solid (57 $\mathrm{mg}, 0.16 \mathrm{mmol}$ ) in a $96 \%$ yield; mp $182-185^{\circ} \mathrm{C}\left(\mathrm{H}_{2} \mathrm{O}\right)$. Anal. $\left(\mathrm{C}_{21} \mathrm{H}_{20} \mathrm{O}_{6}\right) \mathrm{C}, \mathrm{H}$.

11-(5-(Aminopentyl)-4-methyl-1-oxo-3(H)-isobenzofuro[5,6b][1,4]benzodioxine Hydrochloride (16). To a solution containing the corresponding lactone $(\mathbf{1 2 a} ; 15 \mathrm{mg}, 0.045 \mathrm{mmol})$ in methanol $(15 \mathrm{~mL})$ was added $\mathrm{PtO}_{2}(5 \mathrm{mg})$ and two drops of $1 \mathrm{~N} \mathrm{HCl}$. The suspension was stirred at room temperature under hydrogen atmosphere for $12 \mathrm{~h}$. Then the suspension was filtered, and the solvent was removed under vacuum. The residue obtained was diluted with water and extracted with dichloromethane. The organic layers were dried $\left(\mathrm{Na}_{2} \mathrm{SO}_{4}\right)$, filtered, and concentrated under reduced pressure to give the reduced compound $\mathbf{1 6}(15 \mathrm{mg}, 0.04 \mathrm{mmol})$ as a white solid in $88 \%$ yield. Anal. $\left(\mathrm{C}_{20} \mathrm{H}_{22} \mathrm{ClNO}_{4} \cdot \mathrm{H}_{2} \mathrm{O}\right) \mathrm{C}, \mathrm{H}, \mathrm{N}$.

11-(5-(Aminomethyl)pentyl-4-methyl-1-oxo-3(H)-isobenzofuro[5,6-b][1,4]benzodioxine (19). To a solution of the lactone 18a $(20 \mathrm{mg}, 0.05 \mathrm{mmol})$ in DMF $(3 \mathrm{~mL})$ were added $\mathrm{K}_{2} \mathrm{CO}_{3}(22 \mathrm{mg}$, $0.15 \mathrm{mmol}$ ) and methylamine hydrochloride (5 $\mathrm{mg}, 0.08 \mathrm{mmol}$ ). The resulting mixture was stirred seven days at room temperature. Every two days, the same amount of $\mathrm{K}_{2} \mathrm{CO}_{3}$ and methylamine hydrochloride was added. The reaction mixture was diluted with water $(50 \mathrm{~mL})$ and was extracted with ether $(3 \times 12 \mathrm{~mL})$. The organic layer was dried over $\mathrm{Na}_{2} \mathrm{SO}_{4}$, filtered off, and the solvent removed under vacuum. The residue was purified by silica gel column chromatography using hexane/ethyl acetate as eluent, giving the desired amine in $57 \%$ yield; $\mathrm{mp} 114-116^{\circ} \mathrm{C}$ (methanol). Anal. $\left(\mathrm{C}_{20} \mathrm{H}_{21} \mathrm{NO}_{4}\right) \mathrm{C}, \mathrm{H}, \mathrm{N}$.

General Procedure for the Preparation of Hydroxyacids (2234). ortho-Lithiation of Carboxylic Acids (20-21). To a solution of the carboxylic acid $(1 \mathrm{mmol})$ in THF cooled at $-78{ }^{\circ} \mathrm{C}$ was added dropwise LDA ( $2.2 \mathrm{mmol} ; 2 \mathrm{M}$ solution in THF/heptane), and this mixture was stirred. After $3.5 \mathrm{~h}$, the electrophile $(1.2 \mathrm{mmol})$ was added dropwise. The resulting mixture was stirred for $12 \mathrm{~h}$, and then the reaction mixture was allowed to warm to room temperature. A solution of $0.5 \mathrm{~N} \mathrm{HCl}$ was added until the $\mathrm{pH}$ of the mixture was acidic. Then the mixture was stirred at room temperature for $5 \mathrm{~min}$. Finally the reaction mixture was diluted with water and extracted with ether $(4 \times 15 \mathrm{~mL})$. The organic layers were dried $\left(\mathrm{Na}_{2} \mathrm{SO}_{4}\right)$, filtered, and concentrated under reduced pressure. The hydroxyacid was obtained as a white solid that was further transformed into the corresponding lactone.

3-(1-Hydroxyethyl)-1,4-benzodioxin-2-carboxylic Acid (22). Following the general procedure applied to the carboxylic acid $\mathbf{2 0}$ (1 $\mathrm{g}, 5.60 \mathrm{mmol}$ ), the crude residue was purified to furnish the hydroxyacid $(1.19 \mathrm{~g}, 5.36 \mathrm{mmol})$ in a $96 \%$ of yield; $\mathrm{mp} 210-212$ ${ }^{\circ} \mathrm{C}$ (methanol). Anal. $\left(\mathrm{C}_{11} \mathrm{H}_{10} \mathrm{O}_{5}\right) \mathrm{C}, \mathrm{H}$.

3-(1-Hydroxypropyl)-1,4-benzodioxin-2-carboxylic Acid (23). Following the general procedure applied to the carboxylic acid $\mathbf{2 0}$ $(0.8 \mathrm{~g}, 4.20 \mathrm{mmol})$ to furnish the hydroxyacid $\mathbf{2 3}(0.9 \mathrm{~g}, 3.86 \mathrm{mmol})$ in a $92 \%$ yield; $\mathrm{mp} 151-153{ }^{\circ} \mathrm{C}$ (methanol). Anal. $\left(\mathrm{C}_{12} \mathrm{H}_{12} \mathrm{O}_{5}\right) \mathrm{C}$, H.

3-(1-Hydroxybutyl)-1,4-benzodioxin-2-carboxylic Acid (24). Following the general procedure applied to the acid $20(0.78 \mathrm{~g}$, $4.40 \mathrm{mmol})$ furnished the hydroxyacid $24(1.04 \mathrm{~g}, 4.16 \mathrm{mmol})$ in a $95 \%$ yield; mp $152-154{ }^{\circ} \mathrm{C}$ (methanol). Anal. $\left(\mathrm{C}_{13} \mathrm{H}_{14} \mathrm{O}_{5}\right) \mathrm{C}, \mathrm{H}$.

3-(1-Hydroxyhexyl)-1,4-benzodioxin-2-carboxylic Acid (25). Following the general procedure applied to the acid $20(0.95 \mathrm{~g}$, $5.33 \mathrm{mmol})$ furnished the hydroxyacid $25(1.23 \mathrm{~g}, 4.42 \mathrm{mmol})$ in $83 \%$ yield; mp $154-157{ }^{\circ} \mathrm{C}$ (methanol). Anal. $\left(\mathrm{C}_{15} \mathrm{H}_{18} \mathrm{O}_{5}\right) \mathrm{C}, \mathrm{H}$.

3-(1-Hydroxyheptyl)-1,4-benzodioxin-2-carboxylic Acid (26). Following the general procedure applied to the acid 20 (1.01 g, $5.67 \mathrm{mmol})$ furnished the hydroxyacid $26(1.35 \mathrm{~g}, 4.62 \mathrm{mmol})$ in $82 \%$ yield; mp $154-155^{\circ} \mathrm{C}$ (methanol). Anal. $\left(\mathrm{C}_{16} \mathrm{H}_{20} \mathrm{O}_{5}\right) \mathrm{C}, \mathrm{H}$.

3-(1-Hydroxyoctyl)-1,4-benzodioxin-2-carboxylic Acid (27). Following the general procedure applied to the acid 20 (1.31 g, $7.35 \mathrm{mmol})$ furnished the hydroxyacid $27(1.78 \mathrm{~g}, 5.81 \mathrm{mmol})$ in $79 \%$ yield; mp $150-152{ }^{\circ} \mathrm{C}$ (methanol). Anal. $\left(\mathrm{C}_{17} \mathrm{H}_{22} \mathrm{O}_{5}\right) \mathrm{C}, \mathrm{H}$.

3-(1-Hydroxynonyl)-1,4-benzodioxin-2-carboxylic acid (28). Following the general procedure applied to the acid $20(0.98 \mathrm{~g}$, $5.50 \mathrm{mmol})$ furnished the hydroxyacid $28(1.43 \mathrm{~g}, 4.46 \mathrm{mmol})$ in $81 \%$ yield. Mp $148-150{ }^{\circ} \mathrm{C}$ (methanol). Anal. $\left(\mathrm{C}_{18} \mathrm{H}_{24} \mathrm{O}_{5}\right) \mathrm{C}, \mathrm{H}$.

3-(3,5,5-Trimethyl-1-hydroxyhexyl)-1,4-benzodioxin-2-carboxylic Acid (29). Following the general procedure applied to the acid 20 (0.68 g, $3.82 \mathrm{mmol})$ furnished the hydroxyacid $29(1.11 \mathrm{~g}$, $3.19 \mathrm{mmol}$ ) in $83 \%$ yield; $\mathrm{mp} 168-170{ }^{\circ} \mathrm{C}$ (methanol). Anal. $\left(\mathrm{C}_{18} \mathrm{H}_{24} \mathrm{O}_{5}\right) \mathrm{C}, \mathrm{H}$.

3-(5-Bromo-1-hydroxypentyl)-1,4-benzodioxin-2-carboxylic Acid (30). Following the general procedure applied to the acid 20 $(0.87 \mathrm{~g}, 4.90 \mathrm{mmol})$ furnished the hydroxyacid $\mathbf{3 0}$ (1.49 g, 4.32 mmol) in $89 \%$ yield; mp $160-162{ }^{\circ} \mathrm{C}$ (methanol). Anal. $\left(\mathrm{C}_{14} \mathrm{H}_{15^{-}}\right.$ $\left.\mathrm{BrO}_{5}\right) \mathrm{C}, \mathrm{H}$.

3-(2-Benzyloxy-1-hydroxyethyl)-1,4-benzodioxin-2-carboxylic Acid (31). Following the general procedure applied to the acid $20(0.97 \mathrm{~g}, 5.45 \mathrm{mmol})$ furnished the hydroxyacid $\mathbf{3 1}(1.59 \mathrm{~g}, 4.84$ mmol) in $89 \%$ yield; $\mathrm{mp} 145-147{ }^{\circ} \mathrm{C}$ (methanol). Anal. $\left(\mathrm{C}_{18} \mathrm{H}_{16} \mathrm{O}_{6}\right)$ $\mathrm{C}, \mathrm{H}$.

3-(1-Hydroxyhexyl)-6-methoxy-1,4-benzodioxin-2-carboxylic Acid (32). Following the general procedure applied to the acid $21(0.97 \mathrm{~g}, 4.65 \mathrm{mmol})$ furnished the hydroxyacid 32 as colorless oil $(1.19 \mathrm{~g}, 3.86 \mathrm{mmol})$ in $83 \%$ yield. Anal. $\left(\mathrm{C}_{16} \mathrm{H}_{20} \mathrm{O}_{6}\right) \mathrm{C}, \mathrm{H}$.

3-(5-Cyano-1-hydroxypentyl)-1,4-benzodioxin-2-carboxylic Acid (33). Following the general procedure applied to the acid $20(0.72$ $\mathrm{g}, 4.04 \mathrm{mmol})$ furnished the hydroxyacid $33(0.88 \mathrm{~g}, 3.10 \mathrm{mmol})$ in $76 \%$ yield; mp $158-160{ }^{\circ} \mathrm{C}$ (methanol). Anal. $\left(\mathrm{C}_{15} \mathrm{H}_{15} \mathrm{NO}_{5}\right) \mathrm{C}$, $\mathrm{H}, \mathrm{N}$.

3-(6-Cyano-1-hydroxyhexyl)-1,4-benzodioxin-2-carboxylic Acid (34). Following the general procedure applied to the acid $\mathbf{3 0}(0.53$ $\mathrm{g}, 2.96 \mathrm{mmol})$ furnished the hydroxyacid $34(0.67 \mathrm{~g}, 2.21 \mathrm{mmol})$ in $75 \%$ yield; mp $162-163{ }^{\circ} \mathrm{C}$ (methanol). Anal. $\left(\mathrm{C}_{16} \mathrm{H}_{17} \mathrm{NO}_{5}\right) \mathrm{C}$, H, N.

Preparation of Lactones (35-47). Lactonization of Hydroxyacids (22-34). General Procedure. To a solution of the carboxylic acid $(1 \mathrm{mmol})$ in dry toluene $(25 \mathrm{~mL})$ under an argon atmosphere were added PTSA (catalytic amount) and molecular sieves of $4 \AA$ $(100 \mathrm{mg})$, and the mixture was refluxed for $12 \mathrm{~h}$. Then the suspension was filtered and washed with ethyl acetate. The crude product was extracted with ether and washed with $1 \mathrm{~N} \mathrm{NaOH}$ until 
basic $\mathrm{pH}$. The obtained residue was purified by column chromatography on silica gel eluting with hexane/ethyl acetate mixtures.

3-Methyl-1-oxo-3(H)-furo[3,4-b][1,4]benzodioxine (35). Starting from the hydroxyacid $22(0.95 \mathrm{~g}, 4.28 \mathrm{mmol})$ and following the general procedure, the lactone $35(0.78 \mathrm{~g}, 3.82 \mathrm{mmol})$ was obtained as a white solid. The crude product was purified on silica gel column, eluting with hexane/ethyl acetate (7/3), to furnish the desired lactone in $89 \%$ yield; $\mathrm{mp} 125-127{ }^{\circ} \mathrm{C}$ (hexane/ethyl acetate). Anal. $\left(\mathrm{C}_{11} \mathrm{H}_{8} \mathrm{O}_{4}\right) \mathrm{C}, \mathrm{H}$.

3-Ethyl-1-oxo-3(H)-furo[3,4-b][1,4]benzodioxine (36). Starting from the hydroxyacid $23(0.7 \mathrm{~g}, 3.02 \mathrm{mmol})$ and following the general procedure, the lactone $\mathbf{3 6}(0.55 \mathrm{~g}, 2.57 \mathrm{mmol})$ was obtained as a white solid. The crude product was purified on silica gel column, eluting with hexane/ethyl acetate (7/3), to furnish the desired lactone in $85 \%$ yield. Anal. $\left(\mathrm{C}_{12} \mathrm{H}_{10} \mathrm{O}_{4}\right) \mathrm{C}, \mathrm{H}$.

3-Propyl-1-oxo-3(H)-furo[3,4-b][1,4]benzodioxine (37). Starting from the hydroxyacid $24(1.1 \mathrm{~g}, 4.40 \mathrm{mmol})$ and following the general procedure, the lactone $37(0.88 \mathrm{~g}, 3.79 \mathrm{mmol})$ was obtained as a white solid. The crude product was purified on silica gel column, eluting with hexane/ethyl acetate (7/3), to furnish the desired lactone in $86 \%$ yield; $\mathrm{mp} 80-81{ }^{\circ} \mathrm{C}$ (hexane/ethyl acetate). Anal. $\left(\mathrm{C}_{13} \mathrm{H}_{12} \mathrm{O}_{4}\right) \mathrm{C}, \mathrm{H}$.

3-Pentyl-1-oxo-3(H)-furo[3,4-b][1,4]benzodioxine (38). Starting from the hydroxyacid $25(0.63 \mathrm{~g}, 2.26 \mathrm{mmol})$ and following the general procedure, the lactone $38(0.51 \mathrm{~g}, 1.96 \mathrm{mmol})$ was obtained as a white solid. The crude product was purified on silica gel column, eluting with hexane/ethyl acetate (7/3), to furnish the desired lactone in $87 \%$ yield; $\mathrm{mp} 92-93^{\circ} \mathrm{C}$ (hexane/ethyl acetate). Anal. $\left(\mathrm{C}_{15} \mathrm{H}_{16} \mathrm{O}_{4}\right) \mathrm{C}, \mathrm{H}$.

3-Hexyl-1-oxo-3(H)-furo[3,4-b][1,4]benzodioxine (39). Starting from the hydroxyacid $26(0.74 \mathrm{~g}, 2.52 \mathrm{mmol})$ and following the general procedure, the lactone $39(0.63 \mathrm{~g}, 2.30 \mathrm{mmol})$ was obtained as a white solid. The crude product was purified on a silica gel column, eluting with hexane/ethyl acetate $(8 / 2)$, to furnish the desired lactone in $91 \%$ yield; $\mathrm{mp} 82-83^{\circ} \mathrm{C}$ (hexane/ethyl acetate). Anal. $\left(\mathrm{C}_{16} \mathrm{H}_{18} \mathrm{O}_{4}\right) \mathrm{C}, \mathrm{H}$.

3-Heptyl-1-oxo-3(H)-furo[3,4-b][1,4]benzodioxine (40). Starting from the hydroxyacid $27(0.99 \mathrm{~g}, 3.22 \mathrm{mmol})$ and following the general procedure, the lactone $\mathbf{4 0}(0.79 \mathrm{~g}, 2.74 \mathrm{mmol})$ was obtained as a white solid. The crude product was purified on silica gel column, eluting with hexane/ethyl acetate $(8 / 2)$, to furnish the desired lactone in $85 \%$ yield; $\mathrm{mp} 84-85^{\circ} \mathrm{C}$ (hexane/ethyl acetate). Anal. $\left(\mathrm{C}_{17} \mathrm{H}_{20} \mathrm{O}_{4}\right) \mathrm{C}, \mathrm{H}$.

3-Octyl-1-oxo-3 $(H)$-furo[3,4-b][1,4] $]^{4}$ benzodioxine (41). Starting from the hydroxyacid $28(1.13 \mathrm{~g}, 3.53 \mathrm{mmol})$ and following the general procedure, the lactone $\mathbf{4 1}(0.88 \mathrm{~g}, 2.91 \mathrm{mmol})$ was obtained as a white solid. The crude product was purified on silica gel column, eluting with hexane/ethyl acetate $(8 / 2)$, to furnish the desired lactone in $82 \%$ yield; $\mathrm{mp} 82-83{ }^{\circ} \mathrm{C}$ (hexane/ethyl acetate). Anal. $\left(\mathrm{C}_{18} \mathrm{H}_{22} \mathrm{O}_{4}\right) \mathrm{C}, \mathrm{H}$.

3-(2,4,4-Trimethylpentyl)-1-oxo-3(H)-furo[3,4-b][1,4]benzodioxine (42). Starting from the hydroxyacid 29 (1.11 g, $3.19 \mathrm{mmol})$ and following the general procedure, the lactone $\mathbf{4 2}(0.88 \mathrm{~g}, 2.66$ mmol) was obtained as a white solid. The crude product was purified on silica gel column, eluting with hexane/ethyl acetate (8/ 2 ), to furnish the desired lactone in $84 \%$ yield; $\mathrm{mp} 69-70{ }^{\circ} \mathrm{C}$ (hexane/ethyl acetate). Anal. $\left(\mathrm{C}_{18} \mathrm{H}_{22} \mathrm{O}_{4}\right) \mathrm{C}, \mathrm{H}$.

3-(4-Bromobutyl)-1-oxo-3(H)-furo[3,4-b][1,4]benzodioxine (43). Starting from the hydroxyacid $\mathbf{3 0}(0.52 \mathrm{~g}, 1.52 \mathrm{mmol})$ and following the general procedure, the lactone $43(0.41 \mathrm{~g}, 1.26 \mathrm{mmol})$ was obtained as a white solid. The crude product was purified on silica gel column, eluting with hexane/ethyl acetate (7/3), to furnish the desired lactone in $83 \%$ yield; $\mathrm{mp} 82-84^{\circ} \mathrm{C}$ (hexane/ethyl acetate). Anal. $\left(\mathrm{C}_{14} \mathrm{H}_{13} \mathrm{BrO}_{4}\right) \mathrm{C}, \mathrm{H}$.

3-(Benzyloxymethyl)-1-oxo-3(H)-furo[3,4-b][1,4]benzodioxine (44). Starting from the hydroxyacid $31(0.82 \mathrm{~g}, 2.49 \mathrm{mmol})$ and following the general procedure, the lactone $\mathbf{4 4}(0.61 \mathrm{~g}, 1.97$ mmol) was obtained as a white solid. The crude product was purified on silica gel column, eluting with hexane/ethyl acetate (7/ 3 ), to furnish the desired lactone in $79 \%$ yield; mp $95-97{ }^{\circ} \mathrm{C}$ (hexane/ethyl acetate). Anal. $\left(\mathrm{C}_{18} \mathrm{H}_{14} \mathrm{O}_{5}\right) \mathrm{C}, \mathrm{H}$.
6-Methoxy-3-pentyl-1-oxo-3(H)-furo[3,4-b][1,4]benzodioxine (45). Starting from the hydroxyacid $32(0.92 \mathrm{~g}, 2.97 \mathrm{mmol})$ and following the general procedure, the lactone $\mathbf{4 5}(0.77 \mathrm{~g}, 2.65$ mmol) was obtained as a yellow oil. The crude product was purified on silica gel column, eluting with hexane/ethyl acetate (7/3), to furnish the desired lactone in $89 \%$ yield. Anal. $\left(\mathrm{C}_{16} \mathrm{H}_{18} \mathrm{O}_{5}\right) \mathrm{C}, \mathrm{H}$.

3-(4-Cyanobutyl)-1-oxo-3(H)-furo[3,4-b][1,4]benzodioxine (46). Method a. Starting from the hydroxyacid 33 (0.43 g, $1.48 \mathrm{mmol})$ and following the general procedure, the lactone $46(0.32 \mathrm{~g}, 1.20$ mmol) was obtained as a white solid. The crude product was purified on silica gel column, eluting with hexane/ethyl acetate (7/ 3 ), to furnish the desired lactone in $81 \%$ yield; mp $103-105{ }^{\circ} \mathrm{C}$ (hexane/ethyl acetate). Anal. $\left(\mathrm{C}_{15} \mathrm{H}_{13} \mathrm{NO}_{4}\right) \mathrm{C}, \mathrm{H}$.

Method b. To a solution of the corresponding lactone $(110 \mathrm{mg}$, $0.34 \mathrm{mmol})$ in DMF (3 mL) was added HMPA $(1 \mathrm{~mL})$ and $\mathrm{KCN}$ (37 mg, $0.58 \mathrm{mmol}$ ). The obtained mixture was stirred at room temperature for $12 \mathrm{~h}$. Then the solvent was removed and the crude of reaction was purified by silica gel column chromatography to give catechol (32 mg, $0.29 \mathrm{mmol})$.

3-(5-Cyanopentyl)-1-oxo-3(H)-furo[3,4-b][1,4]benzodioxine (47). Starting from the hydroxyacid $34(0.94 \mathrm{~g}, 3.10 \mathrm{mmol})$ and following the general procedure, the lactone $47(0.77 \mathrm{~g}, 2.70 \mathrm{mmol})$ was obtained as a yellow solid. The crude product was purified on silica gel column, eluting with hexane/ethyl acetate (7/3), to furnish the desired lactone in $87 \%$ yield; mp $117-118{ }^{\circ} \mathrm{C}$ (hexane/ethyl acetate). Anal. $\left(\mathrm{C}_{16} \mathrm{H}_{15} \mathrm{NO}_{4}\right) \mathrm{C}, \mathrm{H}, \mathrm{N}$.

Synthesis of Dienes (48-60). General Procedure. The lactone $(1 \mathrm{mmol})$ was dissolved in dry THF $(4 \mathrm{~mL})$ under argon, and the solution was then cooled to $-78^{\circ} \mathrm{C}$. A solution of trimethylsilyl chloride $(6 \mathrm{mmol})$ in THF and the corrresponding alkyllithium (3 mmol) were added with stirring over $5 \mathrm{~min}$, and stirring was continued until the mixture reached room temperature. A solution of $\mathrm{NH}_{4} \mathrm{Cl}(5 \mathrm{~mL})$ was added and the organic layer was separated. The combined organic solutions were dried $\left(\mathrm{Na}_{2} \mathrm{SO}_{4}\right)$, and the solvent was removed to give the crude product. The product was purified by column chromatography (silica gel, hexane/ethyl acetate).

1,3-Dimethylfuro[3,4-b][1,4]benzodioxine (48). Starting from the lactone 35 (631 $\mathrm{mg}, 3.09 \mathrm{mmol})$ and following the general procedure using methyllithium (1.6 M in ether), the furan 48 (531 $\mathrm{mg}, 2.63 \mathrm{mmol}$ ) was obtained as an oil. The crude product was purified on silica gel column, eluting with hexane/ethyl acetate (98/ $2)$, to furnish the desired furan in $85 \%$ yield. Anal. $\left(\mathrm{C}_{12} \mathrm{H}_{10} \mathrm{O}_{3}\right) \mathrm{C}$, $\mathrm{H}$.

1-Ethyl-3-methylfuro[3,4-b][1,4]benzodioxine (49). Starting from the lactone $\mathbf{3 6}$ (501 $\mathrm{mg}, 2.34 \mathrm{mmol})$ and following the general procedure using methyllithium (1.6 $\mathrm{M}$ in ether), the furan 49 (440 $\mathrm{mg}, 2.06 \mathrm{mmol}$ ) was obtained as an oil. The crude product was purified on silica gel column, eluting with hexane/ethyl acetate (98/ 2 ), to furnish the desired furan in $87 \%$ yield. Anal. $\left(\mathrm{C}_{13} \mathrm{H}_{12} \mathrm{O}_{3}\right) \mathrm{C}$, H.

1-Methyl-3-propylfuro[3,4-b][1,4]benzodioxine (50). Starting from the lactone $37(750 \mathrm{mg}, 3.23 \mathrm{mmol})$ and following the general procedure using methyllithium (1.6 $\mathrm{M}$ in ether), the furan $\mathbf{5 0}$ (625 $\mathrm{mg}, 2.71 \mathrm{mmol}$ ) was obtained as an oil. The crude product was purified on silica gel column, eluting with hexane/ethyl acetate (98/ $2)$, to furnish the desired furan in $84 \%$ yield. Anal. $\left(\mathrm{C}_{14} \mathrm{H}_{14} \mathrm{O}_{3}\right) \mathrm{C}$, $\mathrm{H}$.

1-Butyl-3-methylfuro[3,4-b][1,4]benzodioxine (51). Starting from the lactone 35 (523 $\mathrm{mg}, 2.56 \mathrm{mmol})$ and following the general procedure using butyllithium (1.6 M in hexane), the furan $\mathbf{5 1}$ (425 $\mathrm{mg}, 1.74 \mathrm{mmol}$ ) was obtained as an oil. The crude product was purified on silica gel column, eluting with hexane/ethyl acetate (98/ $2)$, to furnish the desired furan in $68 \%$ yield. Anal. $\left(\mathrm{C}_{15} \mathrm{H}_{16} \mathrm{O}_{3}\right) \mathrm{C}$, H.

1-Methyl-3-pentylfuro[3,4-b][1,4]benzodioxine (52). Starting from the lactone $38(541 \mathrm{mg}, 2.08 \mathrm{mmol})$ and following the general procedure using methyllithium (1.6 $\mathrm{M}$ in ether), the furan $\mathbf{5 2}$ (457 $\mathrm{mg}, 1.77 \mathrm{mmol}$ ) was obtained as an oil. The crude product was 
purified on silica gel column, eluting with hexane/ethyl acetate (99/ $1)$, to furnish the desired furan in $85 \%$ yield. Anal. $\left(\mathrm{C}_{16} \mathrm{H}_{18} \mathrm{O}_{3}\right) \mathrm{C}$, H.

1-Hexyl-3-methylfuro[3,4-b][1,4]benzodioxine (53). Starting from the lactone $\mathbf{3 9}(480 \mathrm{mg}, 1.75 \mathrm{mmol})$ and following the general procedure using methyllithium (1.6 M in ether), the furan $\mathbf{5 3}$ (396 $\mathrm{mg}, 1.45 \mathrm{mmol}$ ) was obtained as an oil. The crude product was purified on silica gel column, eluting with hexane/ethyl acetate (99/ 1 ), to furnish the desired furan in $83 \%$ yield. Anal. $\left(\mathrm{C}_{17} \mathrm{H}_{20} \mathrm{O}_{3}\right) \mathrm{C}$, H.

1,3-Dihexylfuro[3,4-b][1,4]benzodioxine (54). Starting from the lactone $39(637 \mathrm{mg}, 2.32 \mathrm{mmol})$ and following the general procedure using hexyllithium (2.5 $\mathrm{M}$ in hexane), the furan $\mathbf{5 4}$ (453 $\mathrm{mg}, 1.32 \mathrm{mmol}$ ) was obtained as an oil. The crude product was purified on silica gel column, eluting with hexane/ethyl acetate (99/ 1), to furnish the desired furan in $87 \%$ yield. Anal. $\left(\mathrm{C}_{22} \mathrm{H}_{30} \mathrm{O}_{3}\right) \mathrm{C}$, $\mathrm{H}$.

1-Heptyl-3-methylfuro[3,4-b][1,4]benzodioxine (55). Starting from the lactone $40(523 \mathrm{mg}, 1.81 \mathrm{mmol})$ and following the general procedure using methyllithium (1.6 M in ether), the furan $\mathbf{5 5}$ (435 $\mathrm{mg}, 1.52 \mathrm{mmol}$ ) was obtained as an oil. The crude product was purified on silica gel column, eluting with hexane/ethyl acetate (99/ 1), to furnish the desired furan in $84 \%$ yield. Anal. $\left(\mathrm{C}_{18} \mathrm{H}_{22} \mathrm{O}_{3}\right) \mathrm{C}$, $\mathrm{H}$.

1-Methyl-3-octylfuro[3,4-b][1,4]benzodioxine (56). Starting from the lactone $41(527 \mathrm{mg}, 1.74 \mathrm{mmol})$ and following the general procedure using methyllithium (1.6 M in ether), the furan $\mathbf{5 6}$ (444 $\mathrm{mg}, 1.49 \mathrm{mmol}$ ) was obtained as an oil. The crude product was purified on silica gel column, eluting with hexane/ethyl acetate (99/ 1), to furnish the desired furan in $85 \%$ yield. Anal. $\left(\mathrm{C}_{19} \mathrm{H}_{24} \mathrm{O}_{3}\right) \mathrm{C}$, $\mathrm{H}$.

3-Methyl-1-(2,4,4-trimethylpentyl)furo[3,4-b][1,4]benzodioxine (57). Starting from the lactone $42(625 \mathrm{mg}, 1.89 \mathrm{mmol})$ and following the general procedure using methyllithium $(1.6 \mathrm{M}$ in ether), the furan 57 (503 $\mathrm{mg}, 1.53 \mathrm{mmol}$ ) was obtained as an oil. The crude product was purified on silica gel column, eluting with hexane/ethyl acetate (98/2), to furnish the desired furan in $87 \%$ yield. Anal. $\left(\mathrm{C}_{19} \mathrm{H}_{24} \mathrm{O}_{3}\right) \mathrm{C}, \mathrm{H}$.

1-(4-Cyanobutyl)-3-methylfuro[3,4-b][1,4]benzodioxine (58). Starting from the lactone 46 (440 $\mathrm{mg}, 1.62 \mathrm{mmol})$ and following the general procedure using methyllithium (1.6 $\mathrm{M}$ in ether), the furan $58(353 \mathrm{mg}, 1.31 \mathrm{mmol})$ was obtained as an oil. The crude product was purified on silica gel column chromatography, eluting with hexane/ethyl acetate (98/2), to furnish the desired furan in $81 \%$ yield. Anal. $\left(\mathrm{C}_{16} \mathrm{H}_{15} \mathrm{NO}_{3}\right) \mathrm{C}, \mathrm{H}, \mathrm{N}$.

1-(5-Cyanopentyl)-3-methylfuro[3,4-b][1,4]benzodioxine (59). Starting from the lactone $47(520 \mathrm{mg}, 1.82 \mathrm{mmol})$ and following the general procedure using methyllithium (1.6 $\mathrm{M}$ in ether), the furan 59 (407 mg, $1.44 \mathrm{mmol}$ ) was obtained as an oil. The crude product was purified on silica gel column, eluting with hexane/ ethyl acetate (98/2), to furnish the desired furan in $79 \%$ yield. Anal. $\left(\mathrm{C}_{17} \mathrm{H}_{17} \mathrm{NO}_{3}\right) \mathrm{C}, \mathrm{H}, \mathrm{N}$.

1-(Benzyloxymethyl)-3-methylfuro[3,4-b][1,4]benzodioxine (60). Starting from the lactone $\mathbf{4 4}(535 \mathrm{mg}, 1.72 \mathrm{mmol})$ and following the general procedure using methyllithium (1.6 M in ether), the furan $60(58 \mathrm{mg}, 0.19 \mathrm{mmol})$ was obtained as an oil. The crude product was purified on silica gel column, eluting with hexane/ ethyl acetate (98/2), to furnish the desired furan in $11 \%$ yield. Anal. $\left(\mathrm{C}_{19} \mathrm{H}_{16} \mathrm{O}_{4}\right) \mathrm{C}, \mathrm{H}$.

1-Methyl-6-methoxy-3-pentylfuro[3,4-b][1,4]benzodioxine (61). Starting from the lactone $45(823 \mathrm{mg}, 2.83 \mathrm{mmol})$ and following the general procedure using methyllithium (1.6 M in ether), the furan $61(677 \mathrm{mg}, 2.34 \mathrm{mmol})$ was obtained as an oil. The crude mixture was purified on silica gel column, eluting with hexane/ ethyl acetate (98/2), to furnish the desired furan in $83 \%$ yield. Anal. $\left(\mathrm{C}_{17} \mathrm{H}_{20} \mathrm{O}_{4}\right) \mathrm{C}, \mathrm{H}$.

1-Methyl-3-(4-bromobutyl)furo[3,4-b][1,4]benzodioxine (62). Starting from the lactone $\mathbf{4 3}(530 \mathrm{mg}, 1.63 \mathrm{mmol})$ and following the general procedure using methyllithium (1.6 $\mathrm{M}$ in ether), the furan 62 (441 mg, $1.52 \mathrm{mmol})$ was obtained as an oil. The crude product was purified on silica gel column, eluting with hexane/ ethyl acetate (99/1), to furnish the desired furan in $84 \%$ yield. Anal. $\left(\mathrm{C}_{15} \mathrm{H}_{15} \mathrm{BrO}_{3}\right) \mathrm{C}, \mathrm{H}$.

\section{Biological Experimental}

Biological Materials. Cell Culture and Cytotoxicity. L1210 leukemia and HT-29 cells were grown in nutrient medium RPMI 1640 or DMEM (Dulbecco's modified Eagle's medium, Sigma, St. Louis, MO), respectively, supplemented with $2 \mathrm{mM}$ L-glutamine, $200 \mathrm{IU} / \mathrm{mL}$ penicillin, $50 \mu \mathrm{g} / \mathrm{mL}$ streptomycin, and $20 \%$ heat inactivated horse serum. They were incubated in a $5 \% \quad \mathrm{CO}_{2}$ atmosphere at $37^{\circ} \mathrm{C}$. For the experiments, the drugs were dissolved in dimethyl sulfoxide $(0.5 \%$ final $)$ and added to the cells in exponential phase of growth at an initial concentration of $0.8 \times$ $10^{5}$ cells $/ \mathrm{mL}$. The cells were counted in quadruplicate after $48 \mathrm{~h}$ for L1210 cells and $96 \mathrm{~h}$ for HT-29 cells with Coultronics Coulter Counter, and results were expressed as the drug concentration that inhibited cell growth by $50 \%$ as compared to the controls $\left(\mathrm{IC}_{50}\right)$. The $\mathrm{IC}_{50}$ values were calculated from regression lines obtained from the probit of the percent cell growth inhibition plotted as a function of the logarithm of the dose. This experiment was performed four independents times in triplicate for every compound.

Inhibition of Cellular Proliferation and Cell Cycle Effects. L1210 leukemia cells were grown in nutrient medium RPMI 1640 supplemented with $2 \mathrm{mM}$ L-glutamine, $200 \mathrm{IU} / \mathrm{mL}$ penicilium, 50 $\mu \mathrm{g} / \mathrm{mL}$ streptomycin, and $20 \%$ heat inactivated horse serum. They were incubated in a $5 \% \mathrm{CO}_{2}$ atmosphere at $37{ }^{\circ} \mathrm{C}$ for $21 \mathrm{~h}$ with several drug concentrations. Cells were fixed by ethanol $(70 \% \mathrm{v} / \mathrm{v})$, then washed, and incubated with PBS containing $100 \mu \mathrm{M}$ RNAse and $25 \mu \mathrm{M} / \mathrm{mL}$ propidium iodide for $30 \mathrm{~min}$ at room temperature. For each concentration, 10-4 cells were analyzed on an Epics XL flow cytomer (Modele Beckman Coulter, French). Results were expressed as a percentage of cells accumulated in each phase of the cell cycle and are indicated.

Effect on Topoisomerase I and II. The complete methodology to measure topoisomerase I and topoisomerase II inhibition by relaxation assay has been previously described. ${ }^{21}$

DNA Interaction. Sequence recognition was determined by DNase I footprinting using a protocol previously described in detail. ${ }^{22}$

Formation of Cleavage Complex. Topoisomerase II Inhibition. Topoisomerase II inhibition activity by $\mathbf{4 a}$ and $\mathbf{1 3 a}$ was measured by quantization of the formation of the cleavage complex on pYRG plasmid DNA by human topoisomerase II (purified from placenta). ${ }^{19}$ The cleavage complex product, linear DNA, was quantized (relative to ellipticine) by densitometric analyses. ${ }^{24}$

\section{Computational Methods}

The molecular geometries of ellipticine and 4,11-dimethyl-1oxo-3 $(H)$-isobenzofuro[5,6- $b][1,4]$ benzodioxine were optimized at the B3LYP/6-31G(d) level of theory. The B3LYP/6-31G(d) electron densities at the optimized geometries were fitted to spherical atomic shell approximation (ASA) expansions ${ }^{25}$ and were used to perform the molecular alignment ${ }^{26}$ of the two structures. Once aligned, the electron densities were computed at the finer level B3LYP/6-311G $(d, p)$ to analyze and visualize the charge distributions and electrostatic potentials. The computation of the molecular geometries, electron densities, and electrostatic potentials was carried out using the Gaussian $03^{27}$ suite of programs. The electron density alignment was produced with ASASim,${ }^{26}$ and the visualization figures were prepared with $\mathrm{VMD}^{28}$ and OpenDX. ${ }^{29}$

Figures were arranged to display electron density isocontours at the aligned positions. A novel visualization technique for the analysis of similarity, that is, isocontour plots of the product of densities, was used. Briefly, the common pattern density $\rho_{\mathrm{CP}}(\mathbf{r})=$ $\rho_{\mathrm{A}}(\mathbf{r}) \rho_{\mathrm{B}}(\mathbf{r})$ on an information or similarity theoretic setting gives the simultaneous probability distribution for the two entities $\rho_{\mathrm{A}}(\mathbf{r})$ and $\rho_{\mathrm{B}}(\mathbf{r})$. If $\mathrm{A}$ and $\mathrm{B}$ were two equal and aligned molecules, $\rho_{\mathrm{CP}^{-}}$ (r) would possess exactly the same set of isocontour surfaces as $\rho_{\mathrm{A}}(\mathbf{r})$, with the values shifted and given by the product $\rho_{\mathrm{A}}(\mathbf{r}) \rho_{\mathrm{A}}(\mathbf{r})$. In general, at the global maximum arrangement of the similarity 
function, $\rho_{\mathrm{CP}}(\mathbf{r})$ displays the largest common pattern (LCP) for the two molecules $\mathrm{A}$ and $\mathrm{B}$.

Acknowledgment. The authors express their gratitude to the Laboratoires Servier (France), Ministerio de Ciencia y Tecnología (MCYT, BQU 2002-00148) and to the Generalitat de Catalunya, Spain (SGR2005-00180), for financial support.

Supporting Information Available: X-ray crystallographic data of $\mathbf{4 a}$, cytotoxicity of $\mathbf{4 a}$ evaluated by the NCI, ${ }^{1} \mathrm{H}$ NMR, ${ }^{13} \mathrm{C}$ NMR, and elemental analysis of all prepared compounds. This material is available free of charge via the Internet at http://pubs.acs.org.

\section{References}

(1) Schepartz, S. A. Introduction and Historial Background. In Cancer Chemotherapeutic Agents, 1st edition; Foye, W. O., Ed.; American Chemical Society: Washington D.C., 1995; pp 1-7.

(2) (a) Doyle, T.-W. In Cancer and Chemotherapy; Crooke, S. T., Prestayko, A. W., Eds.; Academic Press: New York, 1980; Vol. 1, pp 295-305. (b) Carter, S. K.; Bakowski, M. T.; Hellmann, K. In Chemotherapy of Cancer, 3rd edition; John Wiley \& Sons: New York, 1987; pp 43-52. (c) Slichenmyer, W. J.; Rowinsky, E. K.; Donehower, R. C.; Kaufmann, S. H. The Current Status of Camptothecin Analogues as Antitumor Agents. J. Natl. Cancer Inst. 1993, $85,271-278$

(3) (a) Sengupta, S. K. Topoisomerase II inhibitors. In Cancer Chemotherapeutic Agents; Foye, W. O., Ed.; American Chemical Society: Washington, D. C., 1995; pp 246-250. (b) Foye, W. O.; Sengupta, S. K. Cancer Chemotherapy. In Principles of Medicinal Chemistry Foye, W. O., Ed.; American Chemical Society: Washington, D. C., 1995; chapter 37, pp 822-845. (c) Mosher, C. W.; Greus, O. P.; Acton, E. M.; Goodman, L. Preparation and Antitumor Activity of Olivacine and Some Analogs. J. Med. Chem. 1966, 9, 237-241. (d) Kohn, K. W.; Waring, M. J.; Galubiger, D.; Friedman, C. A. Intercalative Binding of Ellipticine to DNA. Cancer Res. 1975, 35, $71-76$.

(4) (a) Jurayj, J.; Haugwitz, R. D.; Varma, R. K.; Paull, K. D.; Barret, J. F.; Cushman, M. Design and Synthesis of Ellipticinium Salts and 1,2-Dihydroellipticines with High Selectivities against Human CNS Cancers In Vitro. J. Med. Chem. 1994, 37, 2190-2197. (b) Sainsbury, M. Ellipticines. In Chemistry of Antitumor Agents; Wilman, D. E. V., Ed.; Chapman and Hall: New York, 1990; pp 410-435.

(5) (a) Auclair, C.; Pierre, A.; Voisin, E.; Pepin, O.; Cros, S.; Colas, C.; Saucier, J. M.; Vershuere, B.; Gros, P.; Paoletti, C. Physicochemical and Pharmacological Properties of the Antitumor Ellipticine Derivatives 2-(2-Diethylaminoethyl)-9-hydroxyellipticinium Chloride, HCl. Cancer Res. 1987, 47, 6254-6261. (b) Pierson, V.; Pierre, A.; Pommier, Y.; Gros, P. Production of the Protein-Associated DNA Breaks by 10 -[Diethylaminopropylamino]-6-methyl-5H-pyrido $\left[3^{\prime}, 4^{\prime}\right.$ : 4,5]pyrrolo[2,3-g]isoquinoline in Cultured L1210 Cells and in Isolated Nuclei: Comparison with Other Topoisomerase II Inhibitors. Cancer Res. 1988, 48, 1404-1409.

(6) (a) Tormo, J. R.; Estornell, E.; Gallardo, T.; Gonzalez, M. C.; Granell, S.; Cortes, D.; Zafra-Polo, M. C. Gamma-Lactone-Functionalized Antitumoral Acetogenins are the Most Potent Inhibitors of Mitochondrial Complex I. Bioorg. Med. Chem. Lett. 2001, 11, 681-684. (b) Quintero, A.; Pelcastre, A.; Solano, J. D. Antitumoral Activity of New Pyrimidine Derivatives of Sesquiterpene Lactones. J. Pharm. Pharmaceut. Sci. 1999, 2, 108-112.

(7) (a) Zavala, F.; Guenard, D.; Robin, J.-P.; Brown, E. StructureAntitubulin Activity Relationships in Steganacin Congeners and Analogs. Inhibition of Tubulin Polymerization In Vitro by ( \pm )Isodeoxypodophyllotoxin. J. Med. Chem. 1980, 23, 546-549. (b) Beard, A. R.; Drew, M. G. B.; Hilgard, P.; Hudson, B. D.; Mann, J.; Neidle, S.; Wong, L. F. T. Podophyllotoxin Analogs: Synthesis and Computer Modeling Investigation of Structure-Activity Relationships. Anticancer Drug Des. 1987, 2, 257-252.

(8) Terada, T.; Fujimoto, K.; Nomura, M.; Yamashita, J.; Wierzba, K.; Yamazaki, R.; Shibata, J.; Sugimoto, Y.; Yamada, Y. Antitumor Agents. 3. Synthesis and Biological Activity of $4 \beta$-Alkyl Derivatives Containing Hydroxy, Amino, and Amido Groups of 4'-O-Demethyl4-desoxypodophyllotoxin as Antitumor Agents. J. Med. Chem. 1993, $36,1689-1699$.

(9) (a) Pujol, M. D.; Romero, M.; Sánchez, I. Synthesis and Biological Activity of New Class of Dioxigenated Anticancer Agents. Curr. Med. Chem.: Anti-Cancer Agents 2005, 5, 215-239. (b) Ruiz, N.; Bouyssou, P.; Maurizis, J. C.; Madelmont, J. C.; Coudert, G. Synthesis of a Benzodioxinic Analogue of Ellipticine and Evaluation of its Antitumor Activity. Heterocycl. Commun. 1997, 3, 509-514.

(10) Ruiz, N.; Buon, C.; Pujol, M. D.; Guillaumet, G.; Coudert, C. DielsAlder Reactions of Furo[3,4-b]1,4-Benzodioxins: An Efficient Approach to Substituted Dibenzo[b,e]1,4-dioxins. Synth. Commun. 1996, 26, 2057-2066.
(11) Bozzo, C.; Pujol, M. D. Study of Preparation of Methylfuro[3,4-b]$[1,4]$ benzodioxinones as Intermediates for the Synthesis of Substituted Polycyclic Systems. Importance of the Acid Used as Catalyst. Tetrahedron 1999, 55, 11843-11852.

(12) Bozzo, C.; Pujol, M. D. Intermolecular Diels-Alder Cycloadditions of Isobenzofuran: A Synthesis of Fused Heterocycles. Heterocycl. Commun. 1996, 2, 163-167.

(13) (a) Gribble, G. W.; Saulnier, M. G.; Sibi, M. P.; Obaza-Nutaitis, J. A. Synthesis and Diels-Alder Reactions of 1,3-Dimethyl-4-(phenylsulfonyl)-4H-furo[3,4- $b$ indole. A New Annulation Strategy for the Construction of Ellipticine and Isoellipticine. J. Org. Chem. 1984, 49, 4518-4523. (b) Smith, J. G.; Welankiwar, S. S.; Shantz, B. S.; Lai, E. H.; Chu, N. G. Synthetic Routes to Derivatives of Polycyclic Aromatic Hydrocarbons Using Isobenzofurans as Transient Reactive Intermediates. J. Org. Chem. 1980, 45, 1817-1824. (c) Newman, M. S.; Cells, J. A. A General Route to 2,3-Diacyl-1,4-dihydro-1,4disubstituted-1,4-epoxynaphtahlenes and 1,4-Disubstituted 2,3-Naphtahlic Anhydrides. J. Org. Chem. 1973, 38, 3482-3487.

(14) (a) Auclair, C. Multimodal Action of Antitumor Agents on DNA: The Ellipticine Series. Arch. Biochem. Biophys. 1987, 259, 1-14. (b) Schwaller, M.-A.; Dodin, G.; Aubard, J. Thermodynamics of Drug-DNA Interactions: Entropy-Driven Intercalation and EnthalpyDriven Outside Binding in the Ellipticine Series. Biopolymers 1996, 50, 510-527. (c) Mauffret, O.; Rene, B.; Convert, O.; Monnot, M.; Lescot, E.; Fernandjian, S. Drug-DNA Interactions: Spectroscopic and Footprinting Studies of Site and Sequence Specificity of Elliptinium. Biopolymers 1991, 31, 1325-1341.

(15) (a) Dodin, G.; Schwaller, M. A.; Aubard, J.; Paoletti, C. Binding of Ellipticine Base and Elliptinium Cation to Calf-Thymus DNA. A Thermodynamic and Kinetic Study. Eur. J. Biochem. 1988, 176, 371-376. (b) Aubard, J.; Levi, G.; Pantigny, J.; Marsault, J. P.; Dodin, G.; Schwaller, M. A. SERS of Ellipticine and Derivatives Free and Bound to DNA. Spec. Publ.-R. Soc. Chem. 1991, 94, 385386. (c) Canals, A.; Purciolas, M.; Aymani, J.; Coll, M. The Anticancer Agent Ellipticine Unwinds DNA by Intercalative Binding in an Orientation Parallel to Base Pairs. Acta Crystallogr., Sect. D 2005, 61 (7), 1009-1012. (d) Cirino, J. J. V.; Belletato, P.; Dantas, S.; Ribeiro, L.; Ferreira, G. R.; dos Santos, H. F. Structure and Properties of Ellipticines. Quim. Nova 2005, 28, 30-36.

(16) (a) Bermejo, A.; Andreu, I.; Suvire, F.; Léonce, S.; Caignard, D. H.; Renard, P.; Pierre, A.; Enriz, R. D.; Cortes, D.; Cabedo, N. Synthesis and Antitumor Targeting G1 Phase of the Cell Cycle of Benzoyldihydroisoquinolines and Related 1-Substituted Isoquinolines. J. Med. Chem. 2002, 45, 5058-5068. (b) Melliou, E.; Magiatis, P.; Mitaku, S.; Skaltsounis, A.-L.; Pierré, A.; Atassi, G.; Renard, P. 2,2-Dimethyl$2 H$-anthra[2,3- $b$ ]pyran-6,11-diones: A New Class of Cytotoxic Compounds. Bioorg. Med. Chem. 2001, 9, 607-612. (c) Wu, J. M.; Shan, F.; Wu, G. S.; Li, Y.; Ding, J.; Xiao, D.; Han, J. X.; Atassi, G.; Léonce, S.; Caignard, D. H.; Renard, P. Synthesis and Cytotoxicity of Artemisinin Derivatives Containing Cyanoarylmethyl Group. Eur. J. Med. Chem. 2001, 36, 469-479. (d) Pierré, A.; Dunn, T. A.; Kraus-Berthier, L.; Léonce, S.; Saint-Dizier, D.; Regnier, G.; Dhainaut, A.; Bizzari, J. P.; Atassi, G. In Vitro and In Vivo Circumvention of Multidrug Resistance by Servier 9788, a Novel Triazinoaminopiperidine Derivative. I. Invest. New Drugs 1992, 10, 137-141. (e) Bojarski, C.; Gitter, A. H.; Bendfeldt, K.; Mankertz, J.; Schmitz, H.; Wagner, S.; Fromm, M.; Schulzke, J. D. Permeability of Human HT-29/B6 Colonic Epithelium as a Function of Apoptosis. J. Physiol. 2001, 535, 541-552.

(17) Experimental design and publicly available data (including the results of this compound reported here) are available at http://dtp.nci.nih.gov/ yacds/default.html.

(18) Le Pecq, J. B.; Dat-Xuong, N.; Gosse, C.; Paoletti, C. A New Antitumoral Agent: 9-Hydroxyellipticine. Possibility of a Rational Design of Anticancerous Drugs in the Series of DNA Intercalating Drugs. Proc. Natl. Acad. Sci. U.S.A. 1974, 71, 5078-5082.

(19) (a) Spitzner, J. R.; Muller, M. T. A. Consensus Sequence for Cleavage by Vertebrate DNA Topoisomerase II. Nucleic Acids Res. 1988, 16 , 5533-5556. (b) Rowe, T. D.; Chen, G. L.; Hsuing, Y. H.; Liu, L. H. Damage by Antitumor Acridines Mediated by Mammalian DNA Topoisomerase II. Cancer Res. 1986, 46, 2021-2026.

(20) (a) Paull, K. D.; Lin, C. M.; Malspeis, L.; Hamel, E. Identification of Novel Antimitotic Agents Acting at the Tubulin Level by Computer-Assisted Evaluation of Differential Cytotoxicity Data. Cancer Res. 1992, 52, 3892-3900. (b) Bai, R.; Paull, K. D.; Herald, C. L.; Malspeis, L.; Petttit, G. R.; Hamel, E. Halichondrin B and Homohalichondrin B, Marine Natural Products Binding in Vinca 
Domain of Tubulin: Discovery of Tubulin-Based Mechanism of Action by Analysis of Differencial Cytotoxicity Data. J. Biol. Chem. 1991, 266, 15882-15889. (c) Schepartz, S. A. Prediction of Biochemical Mechanism of Action from the In Vitro Antitumor Screen of the National Cancer Institute. In Cancer Chemotherapeutic Agents, 1st edition; Foye, W. O., Ed.; American Chemical Society: Washington D.C., 1995; pp 9-46.

(21) Bailly, C.; Arafa, R. K.; Tanious, F. A.; Laine, W.; Tardy, C.; Lansiaux, A.; Colson, P.; Boykin, D. W.; Wilson, W. D. Molecular Determinants for DNA Minor Groove Recognition: Design of a bisGuanidinium Derivative of Ethidium that is Highly Selective for ATRich DNA Sequences. Biochemistry 2005, 44, 1941-1952.

(22) Bailly, C.; Kluza, J.; Martin, C.; Ellis, T.; Waring, M. J. DNase I Footprinting of Small Molecule Binding Sites on DNA. In DNA Synthesis: Methods and Protocols. In Methods in Mol. Biol.; Herdewijn, P., Ed.; Humana Press: Totowa, NJ, 2004; Vol. 288, pp 319-342.

(23) Bailly, C. DNA Relaxation and Cleavage Assays to Study Topoisomerase I Inhibitors. Methods Enzymol. 2001, 340, 610-623.
(24) Fosse, P.; Rene, B.; Charra, M.; Paoletti, C.; Saucier, J. M. Stimulation of Topoisomerase II-Mediated DNA Cleavage by Ellipticine Derivatives: Structure-Activity Relationships. Mol. Pharmacol. 1992, 42, 590-595.

(25) Constans, P.; Carbó, R. Atomic Shell Approximation-ElectronDensity Fitting Algorithm Restricting Coefficients to Positive Values. J. Chem. Inf. Comput. Sci. 1995, 35, 1046-1053.

(26) Constans, P.; Amat, L.; Carbó-Dorca, R. Toward a Global Maximization of the Molecular Similarity Function: Superposition of Two Molecules. J. Comput. Chem. 1997, 18, 826-846.

(27) Frisch, M. J.; Trucks, G. W.; Schlegel, H. B.; Scuseria, G. E.; Robb, M. A.; Cheeseman, J. R.; Vreven, T.; Kudin, K. N.; et al. Gaussian 03, revision B.05; Gaussian, Inc.: Wallingford, CT, 2003.

(28) Humprey, W.; Dalke, A.; Schulten, K. VMD-Visual Molecular Dynamics. J. Mol. Graphics 1996, 14, 33-38.

(29) IBM Open Visualization Data Explorer, version 4.2.0, 2005; http:// www.research. ibm.com/dx.

JM061184G 